\title{
Beyond the risks to food availability - linking climatic hazard vulnerability with the food access of delta-dwelling households
}

\author{
Md Mofakkarul Islam ${ }^{1}$ (D) Md Abdullah Al Mamun ${ }^{2}$
}

Received: 20 February 2019 / Accepted: 20 November 2019 /Published online: 5 December 2019

(C) The Author(s) 2019

\begin{abstract}
Although climate-driven hazards have been widely implicated as a key threat to food security in the delta regions of the developing world, the empirical basis of this assertion has centred predominantly on the food availability dimension of food security. Little is known if climatic hazards could affect the food access of delta-resident households and who is likely to be at risk and why. We explored these questions by using the data from a sample of households resident within the Ganges-BrahmaputraMeghna (GBM) delta in Bangladesh. We used an index-based analytical approach by drawing on the vulnerability and food security literature. We computed separate vulnerability indices for flood, cyclone, and riverbank erosion and assessed their effects on household food access through regression modelling. All three vulnerability types demonstrated significant negative effects on food access; however, only flood vulnerability could significantly reduce a household's food access below an acceptable threshold. Households that were less dependent on natural resources for their livelihoods - including unskilled day labourers and grocery shop owners - were significantly more likely to have unacceptable level of food access due to floods. Adaptive capacity, measured as a function of household asset endowments, proved more important in explaining food access than the exposuresensitivity to flood itself. Accordingly, we argue that improving food security in climatic hazard-prone areas of developing country deltas would require moving beyond agriculture or natural resources focus and promoting hazard-specific, all-inclusive and livelihood-focused asset-building interventions. We provide an example of a framework for such interventions and reflect on our analytical approach.
\end{abstract}

Keywords Climatic hazard · Vulnerability $\cdot$ Food security $\cdot$ Delta $\cdot$ Bangladesh

\section{Introduction}

Several recent reports on the state of food security in the world produced by UN institutions suggest that our target of achieving zero hunger and food security for all by the year 2030, as stated in the UN's Sustainable Development Goal number

Md Mofakkarul Islam

mofakkarul.islam@ntu.ac.uk

Md Abdullah Al Mamun

mamun.ftns@nstu.edu.bd

1 School of Animal, Rural and Environmental Sciences (ARES), Nottingham Trent University, Brackenhurst, Southwell, Nottingham NG25 0QF, UK

2 Department of Food Technology and Nutrition Science (FTNS), Noakhali Science and Technology University, Noakhali, Bangladesh two, ${ }^{1}$ continues to remain elusive. While, in 2014, the number of undernourished people was 795 million (216 million less than the nineties) (FAO et al. 2015), the figure increased to 815 million in 2016 and to 821 million in 2017 (FAO et al. 2018; FAO et al. 2017). Two main reasons for this rise in global hunger and food insecurity have been identified - one is violent conflicts (FAO et al. 2017) and the other is climatedriven hazards arising from climate variability and extremes (FAO et al. 2018). Our focus in this paper is on the latter, i.e. the links between climate-driven hazards and food security. This is an area about which there are significant knowledge gaps and the 2018 UN world food security report (FAO et al. 2018), which focused exclusively on climate change and food security, has called for further studies.

While this topic is global in scope, in this paper, we are primarily concerned with the deltaic regions in the developing

\footnotetext{
${ }^{1}$ This target relates to the Goal\#2 of the UN's Sustainable Development Goals. For details please visit: https://www.un.org/sustainabledevelopment/ hunger/
} 
world - for example, the Ganges-Brahmaputra-Meghna (GBM) and the Mahanadi deltas in Asia as well as the Niger and Nile deltas in Africa. These regions not only have considerable prevalence of food insecurity, but also are widely identified as vulnerable to global climate change and associated hazards (Abdrabo et al. 2015; Arto et al. 2019; Dasgupta et al. 2009; FAO et al. 2018; FAO et al. 2017; Lauria et al. 2018; Nicholls et al. 2018). This vulnerability is linked to their unique physical characteristics (e.g. low elevation from sea level and high flood probabilities) and socio-demographic profiles (e.g. high population density, high prevalence of poverty, and commercial activities) (Alam 2012; Arto et al. 2019; van Driel et al. 2015; Ericson et al. 2006; IPCC 2007; Lauria et al. 2018; Nicholls et al. 2018; Wright et al. 2012). Consequently, developing world deltas are frequently affected by saline water intrusion, floods, riverbank and coastal erosions, underground water depletion, and storms and cyclones (Alam 2012; Arto et al. 2019; Dar et al. 2017; Masterson and Garabedian 2007; McElwee et al. 2017; Neumann et al. 2015; Nicholls et al. 2018; Rasul et al. 2012). Evidence provided in the $2018 \mathrm{UN}$ world food security report (FAO et al. 2018) indicate that such hazards have increased significantly in the last 20 years, with others suggesting that they are likely to aggravate due to global climate change (Dasgupta et al. 2011; IPCC 2007; Nicholls et al. 2018; Woodruff et al. 2013).

The vulnerability of the deltas and its implications for food security have received widespread attention; however, the published research on this issue suffer from notable shortcomings in their focus on the 'human dimension' of climatic hazards and food security. The overwhelming focus has been on the vulnerabilities of the deltas (as physical or ecological entities), rather than on the vulnerabilities of the people living within the deltas. Likewise, concerning food security, the predominant focus has been on the risks to agricultural and fisheries production (usually at sectoral, national, regional, or landscape levels), that is, the availability dimension of food security (Abdrabo et al. 2015; Allison et al. 2009; Arto et al. 2019; Clarke et al. 2018; Dar et al. 2017; Hughes et al. 2012; Krishnamurthy et al. 2014; Lauria et al. 2018; Liersch et al. 2013; Rasul et al. 2012). In comparison, not many published research can be found on the ability of people to access foods, that is, the access dimension of food security. This deficiency has also been noticed by many authors (e.g. Esham et al. 2018; Keller et al. 2018; van Soesbergen et al. 2017). Such shortcomings are counterintuitive, since the term "food security", according to its commonly accepted definition, refers primarily to food access (FAO 1996). Food production or supply is certainly important for food security; however, the research of Nobel Laureate Amartya Sen (Sen 1981) suggests that hunger and famine, the most extreme manifestations of food insecurity, may occur even when foods are available, but people lack the ability to access those foods. This evidence challenged the erstwhile FAD (Food Availability Decline) view ${ }^{2}$ of food insecurity prevalent in the late seventies. It also greatly influenced the redefinition, in the 1996 World Food Summit, of the very concept of "food security" from being a production issue to an access issue. Therefore, there is a need to move beyond national or regional level food availability analysis and focus on food access at the individual and household levels.

Although the $2018 \mathrm{UN}$ world food security report (FAO et al. 2018) touch upon the access issue, the empirical evidence linking climatic hazards and household food access have largely been extrapolated based on the impacts of climatic hazards on agricultural production and trades and the consequent rise in food prices. It is also unclear who in the deltas is likely to be food insecure because of climatic hazards, and why. Although FAO et al. (2018) identifies that the most vulnerable are those whose livelihoods depend on agricultural and natural resources, it provides no direct evidence from the world's deltas.

Accordingly, in this paper we aim to investigate if climatedriven hazards could affect the food access of the households resident within low-lying deltaic zones and who is likely to be at risk and why. To achieve these aims, we use the data collected from a sample of households resident within the Ganges-Brahmaputra-Meghna (GBM) delta in Bangladesh. We apply an index-based analytical approach by drawing on insights from the vulnerability and food security literature. In section 2 we provide the analytical framework and then in section 3 describe the data source and research methods. In section 4 , we present the results of the research and, in section 5 , discuss those results and draw the study's main conclusions.

\section{Analytical framework}

The term "vulnerability" is defined and interpreted in different ways (Cutter et al. 2009; IPCC 2007; Nelson et al. 2010). Here, we refer to the widely-cited definition provided by the Intergovernmental Panel on Climate Change (IPCC) that defines vulnerability as "the degree to which an environmental or social system is susceptible to, and unable to cope with, adverse effects of climate change, including climate variability and extremes" (IPCC 2007: 883). According to the IPCC (2007), "vulnerability" (V) is a function of three variables exposure (E), sensitivity (S), and adaptive capacity (AC). E refers to the exposure of a system to the hazards caused by

\footnotetext{
${ }^{2}$ In his writings Amartya Sen uses the terms "FAD view" or "FAD approach" to refer to the traditional and commonly-found approach to famine explanation in terms of a decline in food availability or supply. This term is now used by others within the development community to refer to the discourses or views that consider food insecurity solely or primarily as a problem of not having adequate food production or supply.
} 
climate variability or extremes, $\mathrm{S}$ refers to the degree to which a system is affected by those hazards, and AC refers to the ability of the system to avoid the damages caused by those hazards. Many authors (Antwi-Agyei et al. 2012; Smit and Wandel 2006) however argue that, at the household level of analysis, it may be difficult to separate E from S. This argument is plausible, since a household cannot incur damage (S), unless E occurs first. Moreover, climatic hazards are macro level incidents (Dilley and Boudreau 2001) which makes it immensely difficult to precisely assess the $\mathrm{E}$ of individual households to a specific hazard. Studies therefore measure $\mathrm{S}$ or $\mathrm{E}$ as an integrated concept at household and even at higher level (Žurovec et al. 2017). Therefore, for household level analysis we could conceptualise V as a function of ES and AC.

The commonly identified climatic hazards which the deltas are exposed to include: sea level rise, tidal surges, floods, tropical cyclones, salinity of soils and water bodies, and riverbank and coastal erosions (Anthony et al. 2015; Das 2017; Duncan et al. 2017; IPCC 2007; McElwee et al. 2017; Neumann et al. 2015; Nguyen 2007; Nicholls et al. 2018; Yang et al. 2011). The harms that these hazards could inflict are well-documented. The key ones include: declining agricultural productivity, destruction of crops, loss of livestock, loss of lives, damage to assets and properties, damage to infrastructure, and disease outbreaks (AMS 1998; Bhattacharjee and Behera 2018; Das 2017; Dar et al. 2017; Duncan et al. 2017; Ericksen et al. 2011; IPCC 2007; Jutla et al. 2013; McElwee et al. 2017; Nguyen 2007; Nicholls et al. 2018).

Although the effects of these ES indicators on household food access in deltas is yet to be empirically established we could expect a link according to Sen's (1981) theory of entitlement. According to Sen, people's ability to access food is mediated through four types of "entitlements" - production (growing food), trade (buying food), own labour (working for food), and inheritance and transfer (receiving foods donated by others). Intuitively, one could argue that the exposure to and damages from climatic hazards could undermine these entitlements. For instance, saline water intrusion and consequent decline in farm productivity may erode a delta-resident household's ability to produce its own foods, i.e. cause a decline in its "production-based entitlement". Disease and/or death of working age family members may reduce a household's ability to access foods through the sale of family labour (i.e. a failure in "labour-based entitlement"). It may also increase the household's burden of care, which, in turn, could affect its ability to buy foods (de Waal and Whiteside 2003). Likewise, loss of livestock could deplete household income and resources (FAO 2016; FAO et al. 2018), leading to a decline in both production and trade-based entitlements (since livestock are sometimes used as buffer during periods of crisis).

Insights from the climate vulnerability literature, however, suggest that the link between ES and food access may not be that straightforward. Humans are not merely the passive recipients of hazards, but they also can adjust to hazards, moderate potential damages, take advantage of opportunities, or cope with the consequences (Adger 1999; IPCC 2007; Vincent and Cull 2010; Vincent 2007). In the literature this is defined as Adaptive Capacity (AC). Accordingly, researchers analyse vulnerability to climatic hazards as $\mathrm{V}=$ ES-AC (e.g. Hughes et al. 2012; Piya et al. 2016). This suggests that ES may not have a direct effect on food access. Rather, the difference between ES-AC, i.e. vulnerability, will determine whether a household's food access will suffer from climatic hazards.

However, confusions are rife as to what exactly determines this AC (Vincent 2007). With insights from the Sustainable Livelihoods literature (Chambers and Conway 1992; DFID 1999), many researchers assess AC indirectly by using a household's possession of five types of assets or capitals human, social, financial, natural, and physical - as proxy indicators (Adger and Kelly 1999; Antwi-Agyei et al. 2012; Piya et al. 2016; Wright et al. 2012). Assets, termed as "endowments", is also a central element in the theory of entitlement (Devereux 2001; Sen 1981). According to Sen, it is by converting their endowments into entitlements that households acquire food. By combining this premise with the asset-based conceptualisation of AC in the climate vulnerability literature, we could argue that the more a household possesses the five types of assets (endowments), the less vulnerable it will be to climatic hazards, and consequently, to the disruption of food access, and vice versa.

The roles of the five types of assets in enabling households to overcome climatic hazards are well-documented in the literature, including examples from developing country deltas (Table 1). In consideration of this evidence and the literature reviewed above, we conceptualise the links between ES, AC, $\mathrm{V}$, and food access as in Fig. 1. Using this framework, we then investigate if there is an effect of ES and an effect of V on household food access and how these effects interact with various livelihood groups living in a delta zone.

\section{Data and methods}

\subsection{Data source}

The data for this study came from a household survey conducted in the Hatiya Upazilla (sub-district) of Noakhali District in the South-eastern part of Bangladeshi coasts. Hatiya is located within the Ganges-Brahmaputra-Meghna (GBM) delta - one of the world's largest deltas covering most of Bangladesh and the Indian state of West Bengal and some parts of China, Nepal, and Bhutan. The GBM delta is formed by the flows of the three major river systems - The Ganges, Brahmaputra, and Meghna. Within the GBM, Hatiya is 
Table 1 Assets and their roles in enabling households to overcome climatic shocks and hazards

\begin{tabular}{|c|c|}
\hline Assets & Roles \\
\hline Physical capital & $\begin{array}{l}\text { Physical assets - such as mobiles, TV, radio - indicate not only status and wealth, but also can help households to } \\
\text { access weather information and early warning. Empirical studies in coastal Bangladesh (Wright et al. 2012) and Sri } \\
\text { Lanka (Thathsarania and Gunaratneb 2018) found strong links between the ownership of these assets and AC. } \\
\text { Ownership of permanent or structurally strong houses can provide securer shelter and thereby improve household } \\
\text { AC and reduce climate-related vulnerabilities, as observed in Vietnam delta (Tran et al. 2017), Sri Lanka } \\
\text { (Thathsarania and Gunaratneb (2018), and Nepal (Piya et al. 2016). }\end{array}$ \\
\hline Social capital & $\begin{array}{l}\text { Social capital in the forms of trust, reciprocity, group memberships, and networks can help households overcome } \\
\text { climatic hazards by improving access to resources, information, institutional assistance, and collective action. } \\
\text { Empirical evidence have been found in the coastal areas of Southeast Asia and the Caribbean (Adger 2003), Sri } \\
\text { Lanka (Thathsarania and Gunaratneb 2018), Ethiopia (Demeke et al. 2011), Nepal (Piya et al. 2016), and coastal } \\
\text { Bangladesh (Jordan 2015; Parvin and Shaw 2013). }\end{array}$ \\
\hline Natural capital & $\begin{array}{l}\text { Natural capital, such as lands and livestock, can help maintain productive activities (e.g. farming), generate income, } \\
\text { and act as insurance in times of crisis. Amount of land ownership had a negative correlation with household } \\
\text { vulnerability to climatic hazards in Vietnam delta (Tran et al. 2017). Household landholding size had positive } \\
\text { effects on AC against floods in the Indian state of West Bengal (Bhattacharjee and Behera 2018) and in the } \\
\text { Mahanadi delta of Odisha, India (Duncan et al. 2017). Livestock ownership improved AC and reduced household } \\
\text { vulnerability to climatic shocks in Ethiopia (Demeke et al. 2011), Peru (Sietz et al. 2012), and Nepal (Piya, Joshi } \\
\text { and Maharjan (2016). }\end{array}$ \\
\hline Human capital & $\begin{array}{l}\text { Higher education increases job opportunities (especially, off-farm employment); increases awareness of hazards and } \\
\text { the ability to understand early warning signals; and thus, can enhance AC and reduce vulnerability. Low education } \\
\text { can have the opposite effects. Empirical evidence have been found in Bangladesh (Collins 2014; Quader et al. } \\
\text { 2017), Vietnam (Tran et al. 2017), Ethiopia (Demeke et al. 2011), Peru (Sietz et al. 2012), Nepal (Piya et al. } \\
\text { (2016), and Sri Lanka (Thathsarania and Gunaratneb 2018). } \\
\text { Dependency ratio (more children and elderly people compared to working age adults) can reduce households' ability } \\
\text { to overcome climatic shocks, e.g. due to burden of care. Evidence comes from the Myanmar delta (Oo et al. 2018), } \\
\text { and Nepal (Piya et al. 2016. } \\
\text { Higher age can reduce physical abilities, thus reducing opportunities for employment and increasing the burden of } \\
\text { care. Younger age can enhance the ability to work and to take quicker actions during hazards, and thus, can } \\
\text { improve adaptive capacity and reduce vulnerability, as found in Sri Lanka (Thathsarania and Gunaratneb 2018) } \\
\text { and the Indian state of West Bengal (Bhattacharjee and Behera 2018). }\end{array}$ \\
\hline Financial capital & $\begin{array}{l}\text { Income and savings can help households cope with climatic hazards, as found in Vietnam (Tran et al. 2017) and } \\
\text { Nepal (Piya et al. 2016). Non-agricultural income can enable households to adapt and quickly recover from } \\
\text { hazards impacts, as observed in Sri Lanka (Thathsarania and Gunaratneb 2018) and the Mahanadi delta (Duncan } \\
\text { et al. 2017) and West Bengal (Bhattacharjee and Behera 2018) in India. }\end{array}$ \\
\hline
\end{tabular}

located at the eastern estuary of the Meghna river. It is formed by "deltaic lobes", which consist of a series of smaller, shallower channels that branched-off from the Meghna river while it emptied into the Bay of Bengal (Fig. 2). Thus, Hatiya looks like an island (and is sometime called as such locally). The island has an area of ca. $1507 \mathrm{Km}^{2}$, of which $20 \%$ is forest reserve and around 22\% is riverine area (BBS 2011).

Hatiya has a population of 453,000 in around 91,000 households (BBS 2011). Agriculture contributes to over $65 \%$ of the income, while non-agricultural labour contributes to $5 \%$, commerce $12 \%$, service $4 \%$, remittance $1 \%$, and others $12 \%$ (Banglapedia 2015). The literacy rate in Hatiya is $34 \%$ which is significantly lower than the national average of $68 \%$. Poverty, on the other hand, is much higher $(64 \%)$ than the national average of $23 \%$ (BBS 2013; BBS 2017), with one earlier study finding over $50 \%$ being landless, two-thirds having a monthly household income of Taka 5,000 only (ca. US\$60), and the vast proportion living in temporary houses with unhygienic hanging latrines (Parvin et al. 2008).

Like other low-lying areas within the GBM delta, Hatiya faces several climate-driven hazards, the most common ones being cyclones, floods, riverbank erosion, and salinity intrusion. The island is in a pathway that cyclones affecting Bangladesh commonly follow. Hatiya experienced disastrous cyclones in 1970, 1985, and 1991, leading to the death of about 130,000 people (Parvin et al. 2008). Successively, Hatiya and the adjoining islands were hit by cyclone Sidr in 2007 and cyclone Aila in 2009, with devastating effects on the houses, crops, household goods, livestock, and income sources of over 100,000 inhabitants in 25,000 households (Alam 2012). The risks are far from being over. In fact, due to rise in temperature, the intensity and frequency of cyclones have increased in Bangladesh, with 70 high intensity cyclones striking the coastal areas in the last 200 years. Of these, $40 \%$ were in the Noakhali and Chittagong zone (Minar et al. 2013). 


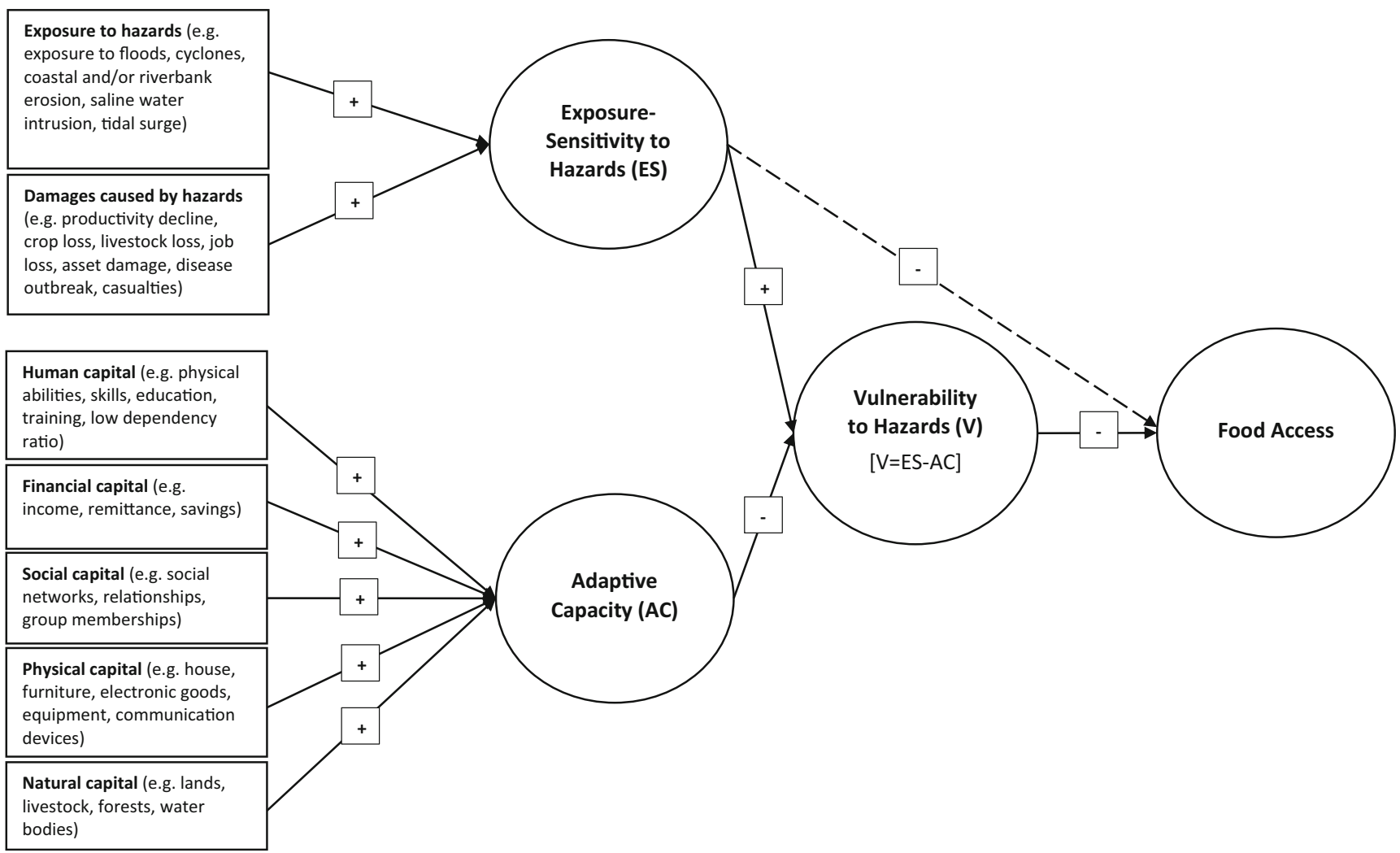

Fig. 1 Conceptual framework showing the links between exposure-sensitivity, adaptive capacity, climatic hazard vulnerability, and household food access (the arrows and the \pm signs indicate expected direction of effects on the corresponding variables; the dashed line indicates a potential effect)

Another major climatic hazard facing Hatiya is floods. As in other parts of the GBM delta, this flooding can be: fluvial floods, tidal floods, fluvio-tidal floods, and storm surge floods (Haque and Nicholls 2018). In Hatiya (and adjacent regions) fluvial flooding occurs during the monsoon season (JuneOctober) when the combined flow of the GBM rivers is drained into the Bay of Bengal through the lower Meghna or via the estuarine networks. Sometimes these flows breach or overtop the polders, causing floods (Haque and Nicholls 2018).

Tidal flooding occurs when the high tides overtop the estuary banks and/or breach the polders. The east of the lower Meghna estuary within which Hatiya is located is particularly vulnerable to tidal flooding as the tidal range is the greatest at this point (Haque and Nicholls 2018). Once overtopped, the flood water inside the polders cannot drain out due to confined sedimentation, causing waterlogging. For example, in August 2013, at least 10 villages in Hatiya were inundated when tidal water breached protective dykes (Star Country Desk 2013). Waterlogging, however, also occurs due to flooding from internal canals and "drainage congestion due to unplanned road networks and confined sedimentation" (Haque and Nicholls 2018: 153).

Fluvio-tidal flooding occurs due to the combined effects of fluvial flows (during monsoon) and high tides. The primary cause of storm surge flooding is tropical cyclones in which high wind speed leads to storm surges, resulting in inundation from the sea and rivers or estuaries. However, a high-intensity cyclone does not always cause major flooding. The risk increases when the cyclone occurs during high tides, rather than low tides (Haque and Nicholls 2018).

Hatiya faces flood risks also because it is situated only $10 \mathrm{~m}$ above the mean sea level, with about $25 \%$ area being below three meters. This low elevation increases its vulnerability to sea level rise experiencing the coastal zone in Bangladesh (Islam et al. 2016; Shamsuddoha and Chowdhury 2007; Siddiqui 2014). The floods can be severe, with a depth as high as $1.83 \mathrm{~m}$ (Siddiqui 2014) and are often accompanied by saline water intrusion. Such floods (and water logging) cause long-lasting damages to agricultural lands, contaminate drinking water, lead to disease outbreaks and damage the already poor infrastructure in Hatiya (Alam 2012; BBS 2013; Parvin and Shaw 2013; Siddiqui 2014).

Furthermore, the northern part of Hatiya has been facing severe riverbank erosion (Parvin et al. 2008; Parvin and Shaw 2013; Siddiqui 2014). Between 1973 and 2016, Hatiya lost an area of over $90 \mathrm{~km}^{2}$ due to erosion (Hassan et al. 2017). This hazard often damages protective embankments, making Hatiya more vulnerable to tidal flooding and saline water intrusion (Siddiqui 2014).

Due to such disaster-proneness, a mangrove afforestation programme, several flood camps and over a hundred cyclone shelters have been established in Hatiya (BBS 2013; Parvin et al. 2008). Moreover, many NGOs operating in Hatiya 

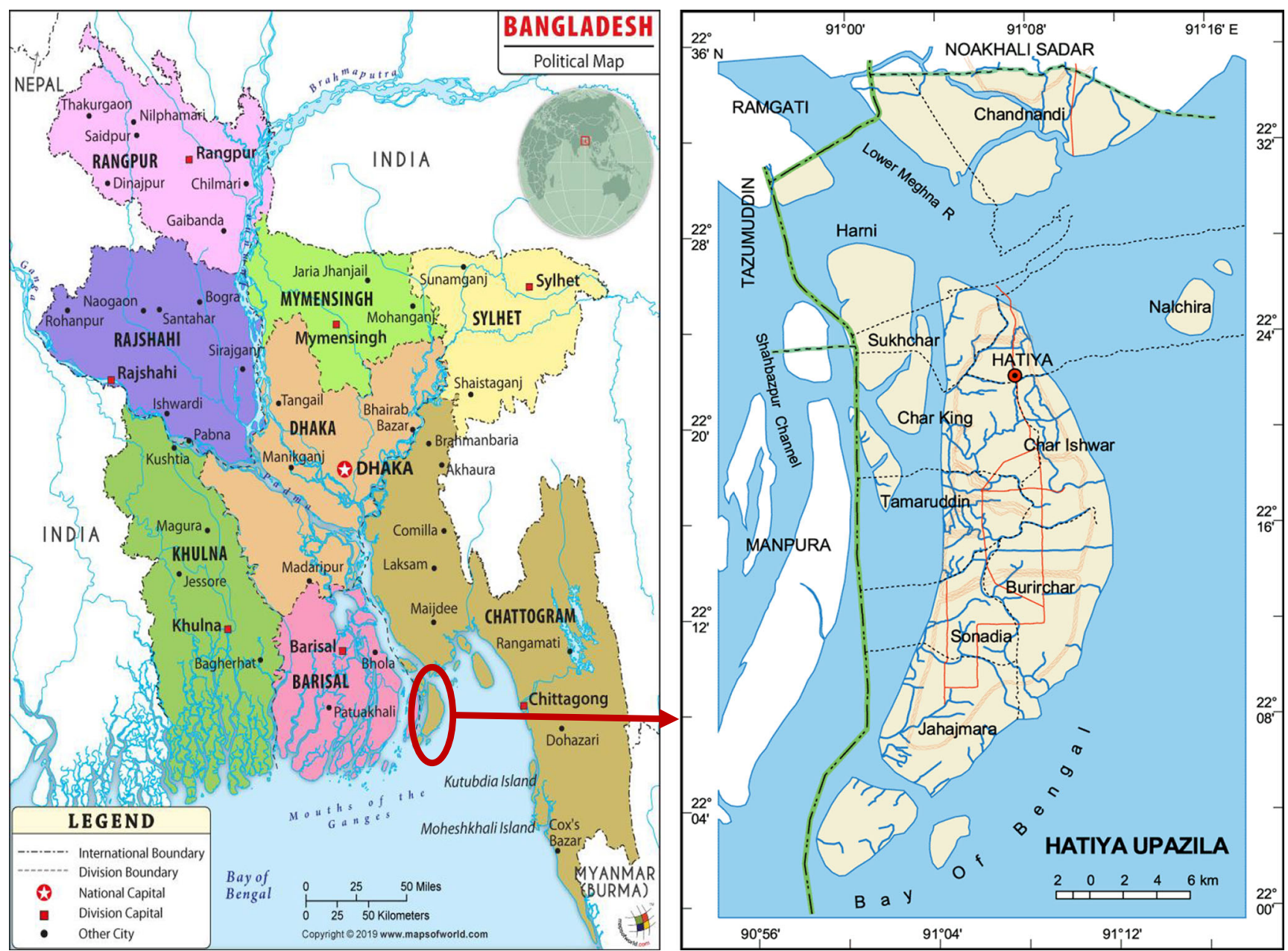

Fig. 2 Maps showing Bangladesh (left) and the study area Hatiya (right) (source: left - Maps of World, https://www.mapsofworld.com/ bangladesh/bangladesh-political-map.html; right - Prime Minister's

Office Library, Dhaka, Government of the People's Republic of Bangladesh, http://lib.pmo.gov.bd/maps/images/noakhali/Hatiya.gif)

provide a range of services, including micro-credit, awareness raising, drinking water purification, installation of sanitary latrines, disaster information, construction of safe houses, and relief (Alam 2012; Parvin et al. 2008).

The above features make Hatiya particularly suitable to achieve the aims of this study. Not only is it highly vulnerable to climate-driven hazards, but also has a high incidence of poverty and food insecurity, including starvation (substantial reduction in meal numbers or not eating at all in a day) to cope with the impacts of climatic hazards (Parvin, Takahashi and Shaw 2008).

Data for this study were collected during May-June 2018. A cluster sampling technique was used. At the initial stage, eight Unions $^{3}$ out of eleven were randomly selected. Then, households from each of these Unions were randomly selected, totalling a sample size of 421 households (Table 2).

\footnotetext{
${ }^{3}$ A Union is the lowest administrative unit at the local government level in Bangladesh
}

A structured questionnaire was used for data collection. It included questions about whether or not the households were exposed to cyclones, floods (tidal/monsoon or seasonal/stormsurge), and riverbank erosion in the last five years, and if yes, whether or not they experienced as a consequence of their exposure to each of these hazards: (i) loss of life, (ii) loss of crops, (iii) loss of livestock, (iv) disease attack, (v) damage to house and/or household goods, and (vi) other damages. The questionnaire also included questions about the demographic characteristics of the households, their food access, and the five types of assets - physical, financial, social, natural, and human capital (Table 3).

The questionnaire was translated from English to $\mathrm{Bangla}^{4}$ and pilot-tested before final administration. The data were collected by the co-author of this paper (assisted by two research assistants) through face-to-face interviews with a member within each of the selected households. Nearly $46 \%$ (192) of the interviewees were household heads (main income

\footnotetext{
${ }^{4}$ Native language of Bangladesh
} 
Table 2 Distribution of the sample used in this study

\begin{tabular}{lll}
\hline Name of Union & Number of households & $\%$ of the total sample \\
\hline Burirchar & 49 & 11.6 \\
Char Ishwar & 54 & 12.8 \\
Tamaruddin & 47 & 11.2 \\
Jahajmara & 50 & 11.9 \\
Char king & 53 & 12.6 \\
Harni & 59 & 14.0 \\
Chandnandi & 57 & 13.5 \\
Nijhum Dwip & 52 & 12.4 \\
Total & 421 & 100.0 \\
\hline
\end{tabular}

earner, almost all of them being males), about $42 \%$ (175) the spouses of the heads, $10 \%$ (43) the adult sons and daughters of the household heads, and the rest $(2.6 \%)$ the other members (e.g. the parents of the household heads living in the same household).

The study was conducted with strict adherence to ethical guidelines. A formal ethical approval was obtained from the authors' affiliated institutions. Informed consents were obtained from the elected Chairperson of the local government in Hatiya and the households before conducting the interviews. Throughout the study anonymity and confidentiality of the participants were strictly maintained.

\subsection{Measurement and analysis}

\subsubsection{Measuring food access}

As many as nine proxy indicators for assessing household food access have been identified, each having unique advantages and limitations (Leroy et al. 2015). We used the Food Consumption Score (FCS) proxy indicator developed and championed by the World Food Programme (WFP 2008). The FCS is one of the methodologically robust and most commonly-used tools for measuring household food access (Leroy et al. 2015; WFP 2008). The FCS was computed as a composite score based on dietary diversity, food frequency, and relative nutritional importance of eight food groups. The questionnaire included location-specific food items for those groups. A seven days recall period was used, as per the WFP (2008) guideline. The respondents were first asked about the number of days each of the listed food items was consumed within the household. Consumption frequencies of the food items were then multiplied by the corresponding food group weights as suggested by WFP (2008). The values were then summed up to obtain the FCS for each household as per eq. 1 .

$$
\begin{aligned}
\text { FCS }= & 2 * x_{\text {staple }}+3 * x_{\text {pulse }}+1 * x_{\text {veg }}+1 * x_{\text {fruit }}+4 * x_{\text {animal }} \\
& +4 * x_{\text {dairy }}+0.5 * x_{\text {sugar }}+0.5 * x_{\text {oil }}
\end{aligned}
$$

Where, $x$ represents the number of days each food item was consumed within a week.

The summated FCS scores were then categorised as: poor (scores up to 28), borderline (scores 28.5 to 42) and acceptable (scores $\geq 42.5$ ) consumptions (WFP 2008). These higher cutoff points were used, since the sampled households and the people in Bangladesh, in general, consume sugar and oil almost every day. Poor and borderline consumption categories together were considered as "unacceptable" food access.

\subsubsection{Measuring exposure-sensitivity (ES), adaptive capacity (AC), and vulnerability (V)}

We used an index based method to measure the ES, AC, and V variables. At first, we created separate indices for ES and AC, and then used these to calculate V (Hahn et al. 2009; Piya et al. 2016). The ES and V indices were for flood, cyclone, and riverbank erosion each. The indicators of these indices were identified from the literature (Table 1) and validated through local consultations in the study area. The indicators, their hypothesised relationships with the corresponding index variables, and their literature sources are provided in Table 3. In the original questionnaire, some variables (e.g. education, income) were measured as ordinal-categorical which were later coded as dummy variables as per guidelines in the literature (Córdova 2008; Filmer and Pritchett 2001; WFP 2017). Some indicator variables with very low $(<5 \%)$ or very high $(>95 \%)$ frequency counts in the data were excluded from analysis (WFP 2017).

After exploratory analyses, all the ES and AC indicators were standardised. Weights for each of the indicators were then calculated. Some studies use an equal weighting method, but due to its arbitrariness it may lead to over- or underweighting of indicators (Piya et al. 2016). Another method, based on expert judgements, may suffer from subjectivity and lack of agreement among experts (Piya et al. 2016). We, therefore, used a popular method based on Principal Component Analysis (PCA). After the seminal work of Filmer and Pritchett (2001), this weighting method is now widely used, not only by researchers (e.g. Piya et al. 2016), but also international programmes like the World Food Programme (WFP 2017), Latin American Public Opinion Project (LAPOP) (Córdova 2008), and the Demographic and Health Surveys (DHS) programme. In the PCA, the indicator loadings on the first principal component (PC1) were taken as the weights of the indicators. Based on these, ES index scores for each of the hazards and for AC were created using eq. 2 (Córdova 2008; Filmer and Pritchett 2001; Piya et al. 2016; WFP 2017).

$I_{j}=\sum_{i=1}^{k} \alpha_{i}\left[\frac{x_{i j}-\bar{x}_{i}}{s_{i}}\right]$ 
Table 3 Indicator variables and their hypothesised relationships with the corresponding index variables

\begin{tabular}{|c|c|c|}
\hline Index variables & Indicators and measurement & Hypothesised relationships* \\
\hline \multirow[t]{7}{*}{ Exposure-Sensitivity } & $\begin{array}{l}\text { Household exposed to flood/cyclone/riverbank } \\
\text { erosion in the last five years }(0,1)\end{array}$ & + \\
\hline & Faced loss of life $(0,1)$ & + \\
\hline & Faced loss of crops $(0,1)$ & + \\
\hline & Faced loss of livestock $(0,1)$ & + \\
\hline & Faced disease attack $(0,1)$ & + \\
\hline & Faced damages to house and/or household goods $(0,1)$ & + \\
\hline & Faced other damages $(0,1)$ & + \\
\hline \multicolumn{3}{|l|}{ Adaptive Capacity } \\
\hline \multirow[t]{4}{*}{ Human capital } & Education of head secondary \& above $(0,1)$ & + \\
\hline & Education of spouse secondary \& above $(0,1)$ & + \\
\hline & Age of head up to 64 years $(0,1)$ & + \\
\hline & Child dependency ratio (continuous) & - \\
\hline \multirow[t]{3}{*}{ Financial capital } & Head income per month above TK $15,000(0,1)$ & + \\
\hline & Spouse has monthly income $(0,1)$ & + \\
\hline & Remittance (US\$ per month)** & + \\
\hline \multirow[t]{4}{*}{ Social capital } & Member of a professional association $(0,1)$ & + \\
\hline & Member of a cultural/sports association $(0,1)$ & + \\
\hline & Member of a religious group/association $(0,1)$ & + \\
\hline & Member of an NGO group/association $(0,1)$ & + \\
\hline \multirow[t]{7}{*}{ Physical capital } & Has two/more house $(0,1)$ & + \\
\hline & Has bicycle/rickshaw $(0,1)$ & + \\
\hline & Has motorbike $(0,1)$ & + \\
\hline & Has TV $(0,1)$ & + \\
\hline & Has radio $(0,1)$ & + \\
\hline & Has two/more mobile phone $(0,1)$ & + \\
\hline & Has smartphone $(0,1)$ & + \\
\hline \multirow[t]{3}{*}{ Natural capital } & Tropical Livestock Unit (scale score)*** & + \\
\hline & Area of farmland (acres) & + \\
\hline & Area of homestead (including ponds) (acres) & + \\
\hline
\end{tabular}

*The hypothesised relationships are based on a review of the literature cited in Table 1

**Converted from local currency (Bangladeshi Taka) @ 1 US\$=TK. 84 as of Nov 2018

$* * *$ Tropical Livestock Unit $(\mathrm{TLU})=($ no. of cows $* 0.7)+($ no. of buffaloes $* 0.7)+($ no. of goats $* 0.1)+($ no. of ducks $* 0.01)+($ no. of chicken $* 0.01)$

Where,

$I_{j} \quad$ Index score of the $j^{\text {th }}$ household $(j=1,2, \ldots \ldots, \mathrm{n})$

$\alpha_{i} \quad$ weight (loading) for the $i^{\text {th }}$ indicator $(i=1,2, \ldots \ldots, \mathrm{k})$ from the first principal component

$x_{i j} \quad$ value of the $i^{\text {th }}$ indicator for the $j$ th household

$\bar{x}_{i} \quad$ mean of the $i^{\text {th }}$ indicator

$s_{i} \quad$ standard deviation of the $i^{\text {th }}$ indicator

The construction of the AC index followed a two-step process (Piya, Joshi and Maharjan 2016). In the first step, index scores for each of the five capitals - human, financial, social, physical, and natural - were calculated using eq. 2 . The resultant five index variables were then used in the second step to calculate the AC index score using the same equation.

Afterwards, the hazard vulnerability index was computed using eq. 3 (Hughes et al. 2012; Piya, Joshi and Maharjan 2016).

$V_{j}=E S I_{j}-A C I_{j}$

Where,
$V_{j} \quad$ Vulnerability index score of the $j^{\text {th }}$ household $(j=$ $1,2, \ldots \ldots \ldots, n)$ for the corresponding hazard (i.e. flood or cyclone or riverbank erosion)

$E S I_{j} \quad$ Exposure-Sensitivity index score of the $j^{\text {th }}$ household for the corresponding hazard

$A C I_{j} \quad$ Adaptive Capacity index score of the $j^{\text {th }}$ household

For each household, separate vulnerability index scores for each of the three hazards - flood, cyclone, and riverbank erosion - were created.

To identify patterns in the data, exploratory analyses of the $\mathrm{ES}$ and $\mathrm{AC}$ variables were performed before moving on to confirmatory analyses through regression modelling.

\subsubsection{Estimating the effects of exposure-sensitivity (ES) and vulnerability (V) on food access}

To test the effects of the ES and the V variables on household food access we used a generalised linear regression model (GLiM) in SPSS Statistics version 25. We chose a GLiM as this procedure does not require the dependent variable to have a normal distribution and the data to be transformed (Agriesti 
2007). The GLiM also offers the flexibility to model various kinds of distribution, including binomial. Our FCS data displayed a non-normal distribution (Fig. 3) and we wanted to model the binary outcome of the FCS (i.e. unacceptable and acceptable food access). Hence, the GLiM procedure was appropriate for us. The GLiM can be expressed as in eq. 4 .

$E(F C S)=g(\mu)=\beta_{0}+\sum \beta_{i} x_{i}$

Where,

$E(F C S)$ Expected values (means) of the Food Consumption Score (FCS) variable

$g(\mu) \quad$ the link function (Identity) of FCS which in this case is the same as $E(F C S)$ (i.e. no transformation is made in the dependent variable FCS)

$x_{i} \quad$ the ES index variables for flood, cyclone, and riverbank erosion (to test the effects of ES on food access) or the $\mathrm{V}$ index variables for flood, cyclone, and riverbank erosion (to test the effects of $\mathrm{V}$ on food access)

$\beta_{0} \quad$ intercept of the model

$\beta_{i} \quad$ regression coefficients

Afterwards, we categorised the FCS scores into a binary variable - "unacceptable access" (FCS scores $\leq 42)$ (coded 1$)$ and "acceptable access" (FCS scores $\geq 42.5$ ) (coded 0) - and fitted the variable into a binary logistic regression model (eq. 5) in order to estimate the likelihood of a household having unacceptable food access. For this as well, we used the GLiM procedure in SPSS version 25.

$\ln \left(\frac{p}{1-p}\right)=\beta_{0}+\sum \beta_{i} x_{i}$

Where,

$\begin{array}{ll}p & \begin{array}{l}\text { the probability that the FCS variable takes the } \\ \text { value of } 1 \text { (i.e. } \text { unacceptable access) } \\ \text { the odds of a household falling within the }\end{array} \\ \frac{p}{1-p} & \begin{array}{l}\text { unacceptable access category } \\ \text { the log link (Logit) of the FCS variable }\end{array}\end{array}$

We then estimated the odds of a household becoming food insecure from eq. 6 .

$\frac{p}{1-p}=e^{\beta_{0}+\sum \beta_{i} x_{i}}$

Then, to identify which occupation groups in Hatiya were likely to be affected, we estimated the "interaction effects" between the statistically significant vulnerability variable(s) in eq. 5 and the "main occupation of household head" variable (having seven categories - unskilled labourer, farmer, fisherman, office employee, boatman, driver, and grocer). The odds of each of these occupation groups to have unacceptable food access were then calculated from eq. 6 .

\section{Results}

\subsection{Food access}

The aggregate Food Consumption Scores ranged from 25.00 to 105.50 , with a mean of 53.97 and standard deviation of 15.90. The distribution of the scores was non-normal (Fig. 3). According to WFP's (2008) suggested cut-off points, only $1.9 \%$ of the households had poor consumption (scores up to 28 ), nearly $24 \%$ had borderline consumption (scores 28.5 to 42 ), and over $74 \%$ had acceptable consumption (scores 242.5) (Fig. 4). The poor and borderline categories combined,

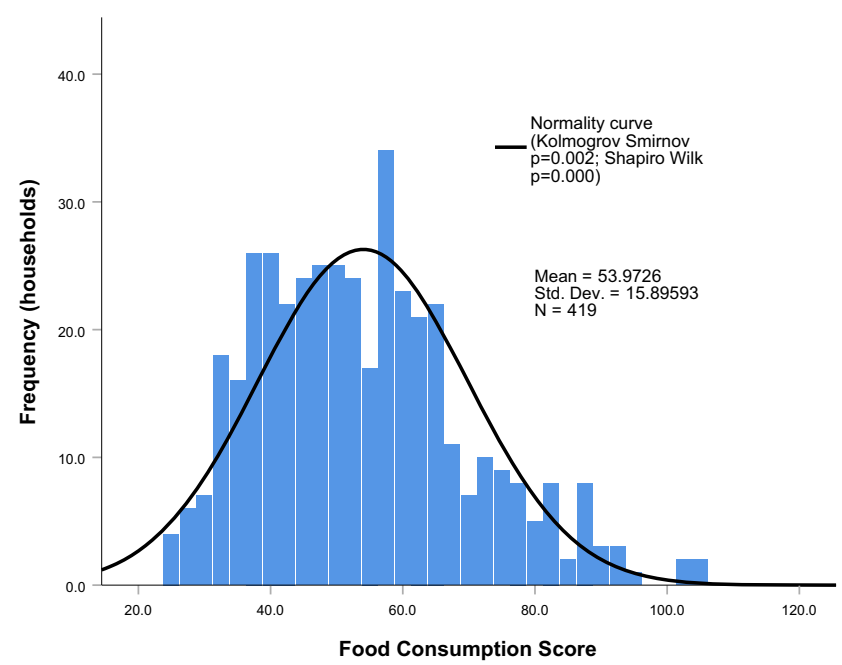

Fig. 3 Food Consumption Scores (FCSs) of the sample households in Hatiya

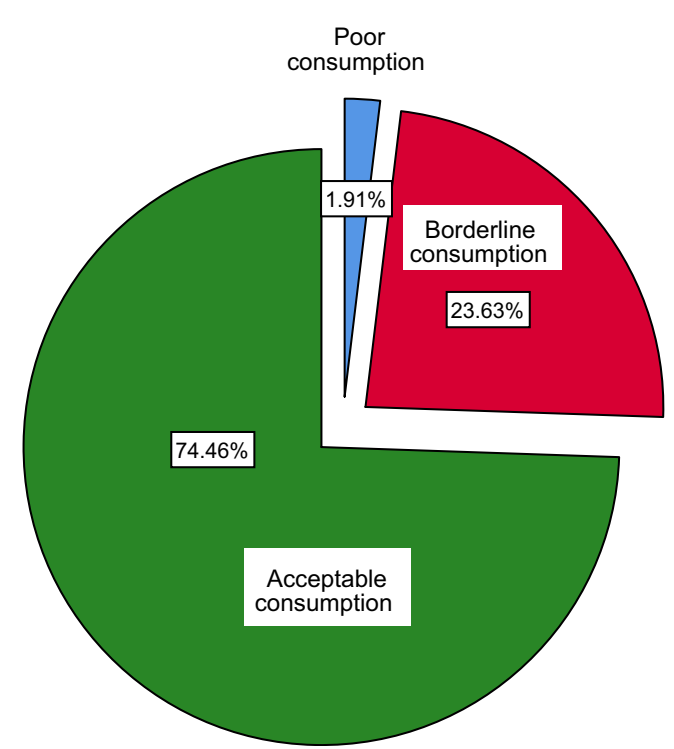

Fig. 4 FCS categories of the sample households in Hatiya 
Table 4 Food access according to household head's main occupation

\begin{tabular}{llll}
\hline Household head's main occupation & Acceptable food access & Unacceptable food access & Total \\
\hline Unskilled & $69(16.5)$ & $28(6.7)$ & $97(23.2)$ \\
Farming & $82(19.6)$ & $29(6.9)$ & $111(26.5)$ \\
Fishing & $71(16.9)$ & $16(3.8)$ & $87(20.8)$ \\
Office job & $21(5.0)$ & $6(1.4)$ & $27(6.4)$ \\
Boatman & $27(6.4)$ & $7(1.7)$ & $34(8.1)$ \\
Driver & $17(4.1)$ & $12(2.9)$ & $29(6.9)$ \\
Grocer & $25(6.0)$ & $9(2.1)$ & $34(8.1)$ \\
Total & $312(74.46 \%)$ & $107(25.54 \%)$ & $419(100 \%)$ \\
\hline
\end{tabular}

Figures within parentheses represent percentages of the total sample ( 419 households; 2 missing values) slightly over $25 \%$ of the households in Hatiya had unacceptable food access.

The distribution of the households within the acceptable and unacceptable categories according to the "household head's main occupation" is shown in Table 4. The sample includes proportional representation of both the food access categories within each of the occupation types. However, over $70 \%$ the sample consists of the unskilled, farming, and fishing categories.

\subsection{Exposure-sensitivity (ES)}

The descriptive statistics of the ES index variables along with the weights of their corresponding indicators obtained through Principal Component Analyses (PCA) are provided in Table 5. As hypothesised (Table 3), all the indicators loaded positively on the ES indices. Within each ES category, exposure to the hazard itself had the highest loadings. Concerning damages, livestock loss had the highest weights within the flood index, followed by disease attack, and damage to houses/household goods. Within the cyclone index, damage to houses/household goods had the highest weight, the second and third highest being livestock loss and crop loss, respectively. Damage to houses/household goods had the highest weights within the riverbank ES, followed by livestock and crop losses. Across the three ES types, damage to houses/household goods and livestock loss were the common, high-impact damages. Crop loss was not strongly associated with floods and caused mostly by riverbank erosion and cyclones. Disease attacks contributed highly to flood ES. Loss of life did not come out as a significant indicator in any of the three ESs.

Table 5 Descriptive statistics and weights (loadings) of the Exposure-Sensitivity indicators

\begin{tabular}{|c|c|c|c|c|c|c|c|c|c|c|c|c|}
\hline \multirow[t]{2}{*}{ ES Indicators } & \multicolumn{4}{|l|}{ Flood } & \multicolumn{4}{|l|}{ Cyclone } & \multicolumn{4}{|c|}{ Riverbank erosion } \\
\hline & Min-Max & Mean & S.D. & Weight & Min-Max & Mean & S.D. & Weight & Min-Max & Mean & S.D. & Weight \\
\hline $\begin{array}{l}\text { Household exposed to the said } \\
\text { hazard within the last five } \\
\text { years }(0,1)^{\mathrm{a}}\end{array}$ & - & 0.86 & 0.345 & 0.858 & - & 0.39 & 0.487 & 0.907 & - & 0.70 & 0.459 & 0.921 \\
\hline Faced loss of life $(0,1)$ & - & 0.16 & 0.364 & $\mathrm{NE}^{\mathrm{b}}$ & - & 0.00 & 0.000 & $\mathrm{NE}^{\mathrm{b}}$ & - & $0.045^{\mathrm{b}}$ & 0.208 & $\mathrm{NE}^{\mathrm{b}}$ \\
\hline Faced loss of crops $(0,1)$ & - & 0.42 & 0.493 & 0.447 & - & 0.14 & 0.345 & 0.679 & - & 0.44 & 0.497 & 0.708 \\
\hline Faced disease attack $(0,1)$ & - & 0.60 & 0.490 & 0.747 & - & 0.09 & 0.291 & 0.647 & - & 0.28 & 0.451 & 0.568 \\
\hline Faced loss of livestock $(0,1)$ & - & 0.71 & 0.454 & 0.789 & - & 0.23 & 0.422 & 0.844 & - & 0.48 & 0.500 & 0.787 \\
\hline $\begin{array}{l}\text { Faced damage to } \\
\text { house/household } \\
\text { goods }(0,1)\end{array}$ & - & 0.71 & 0.453 & 0.729 & - & 0.35 & 0.479 & 0.875 & - & 0.68 & 0.468 & 0.890 \\
\hline Faced other damages $(0,1)$ & - & 0.02 & 0.128 & $\mathrm{NE}$ & - & 0.01 & 0.084 & $\mathrm{NE}$ & - & 0.01 & 0.097 & $\mathrm{NE}$ \\
\hline ES Indices & $\begin{array}{l}\operatorname{Min}-5.81 \\
\operatorname{Max} 2.45\end{array}$ & 0.0076 & 2.6484 & - & $\begin{array}{l}\operatorname{Min}-2.30 \\
\operatorname{Max} 7.58\end{array}$ & 0.0052 & 3.1808 & - & $\begin{array}{l}\operatorname{Min}-4.43 \\
\operatorname{Max} 3.73\end{array}$ & -0.0035 & 3.0813 & - \\
\hline
\end{tabular}

${ }^{a}$ In the survey the respondents were also asked about the number of each events and the duration to which their household was exposed to each, but only a few of them could answer those questions

${ }^{\mathrm{b}}$ Not Estimated (NE): excluded from PCA and index construction since these indicators have $<5 \%$ occurrence for some or all of the hazards (e.g. see guidance in Córdova 2008; and WFP 2017)

For flood ES, Eigenvalue of the first principal component $(\mathrm{PC} 1)=2.647$; variance explained by $\mathrm{PC} 1=52.936$

For cyclone ES, Eigenvalue of $\mathrm{PC} 1=3.180$; variance explained by $\mathrm{PC} 1=63.610$

For riverbank erosion ES, Eigenvalue of $\mathrm{PC} 1=3.081$; variance explained by $\mathrm{PC} 1=61.623$ 
Exploratory analysis of the ES index scores did not reveal statistically significant correlations with the Food Consumption Scores (FCSs) (Fig. 5).

By treating the FCS as a binary variable - unacceptable access and acceptable access - and disaggregating the ES scores between these two categories we found that the households within the former were affected more by floods, whilst those in the later by riverbank erosion and cyclone (Fig. 6). This suggested a possible link between flood ES and unacceptable food access in Hatiya.
Fig. 5 Scatterplots showing the spread and correlations of the ES index variables with the FCSs
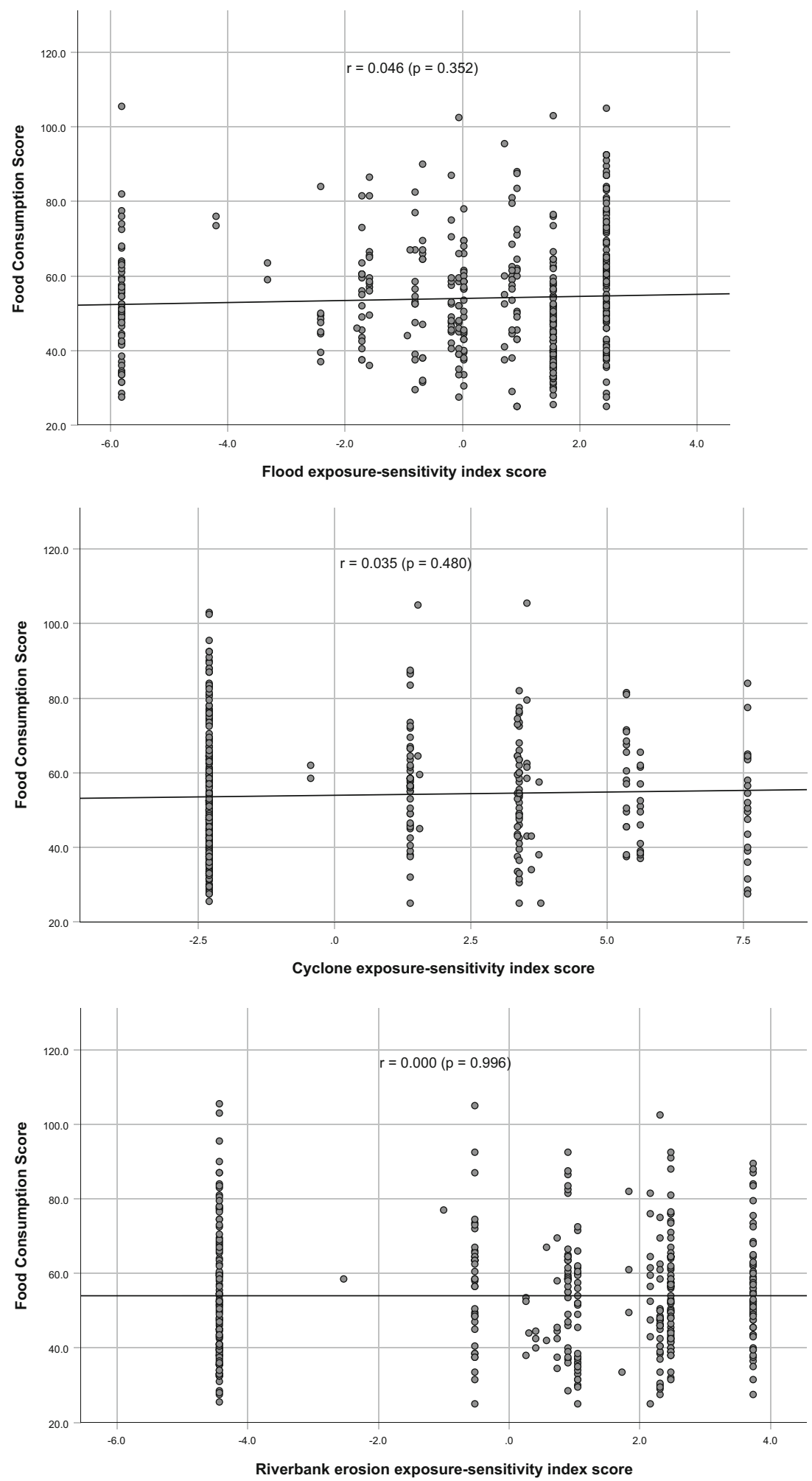
Fig. 6 Mean ES index scores within acceptable and unacceptable food access categories
Food access

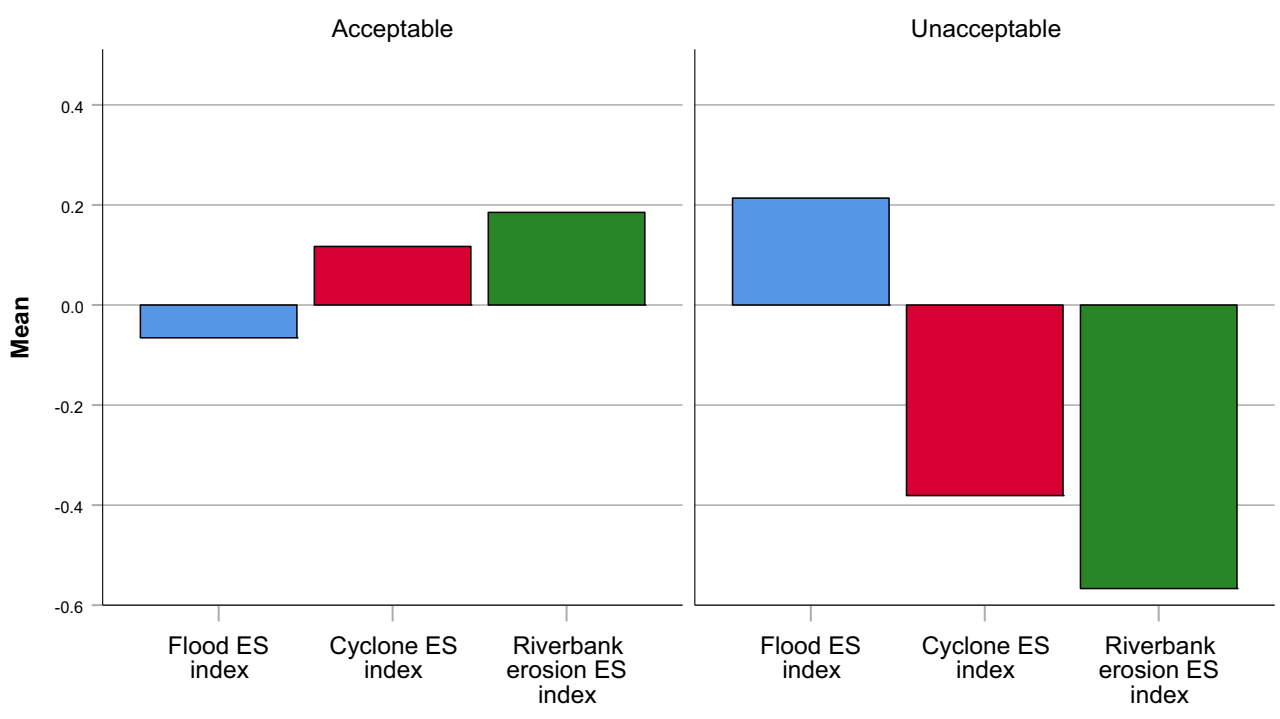

By disaggregating the ES indices and food access categories according to the household heads' main occupation, we found that flood ES was the highest amongst the grocer within the unacceptable category (Fig. 7). Another group, driver within the unacceptable category, also had a higher flood ES compared to its counterpart in the acceptable category and so was the case of the unskilled. It suggested that flood ES might have a connection with unacceptable food access among the grocers, drivers, and unskilled labourers. However, the results did not show a clear pattern, since some groups, such as office employee and boatman, had higher flood ES within the acceptable category (Fig. 7).

\subsection{Adaptive capacity (AC)}

The AC index was constructed in two steps. First, index scores for the five capitals - human, financial, social, physical, and natural - were created. Second, these five indices were then aggregated to create the AC index. The descriptive statistics of these indices, along with the weights of their corresponding indicators, are provided in Table 6.

Within the human capital (HC) index, the highest weightings ( 0.802 and 0.801 ) were for the education (secondary and above) of household heads and spouses. Unexpectedly, however, child dependency ratio had a very small (0.052), but positive loading on HC.

Fig. 7 Mean ES index scores of occupation groups within the unacceptable and acceptable categories
Food access

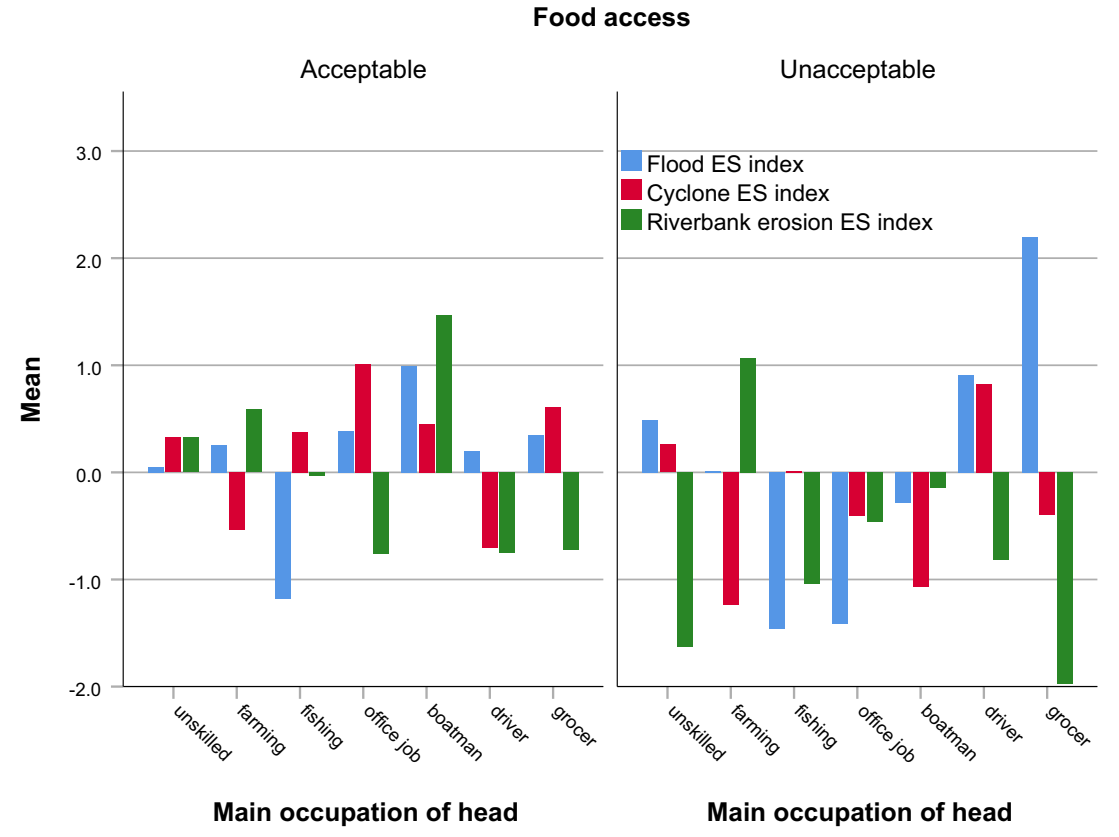


Table 6 Descriptive statistics of the Adaptive Capacity indicator variables

\begin{tabular}{|c|c|c|c|c|}
\hline Variables & Min-Max & Mean & S.D. & Weight \\
\hline Human capital & $\begin{array}{l}\text { Min }-1.89 \\
\text { Max } 3.91\end{array}$ & .0052 & 1.39898 & 0.506 \\
\hline Education of head secondary \& above $(0,1)$ & & 0.16 & 0.366 & 0.801 \\
\hline Education spouse secondary $\&$ above $(0,1)$ & & 0.15 & 0.361 & 0.802 \\
\hline Age of head up to 64 years $(0,1)$ & & 0.92 & 0.273 & 0.334 \\
\hline Child dependency ratio (continuous) & & 97.09 & 60.966 & 0.052 \\
\hline Financial capital & $\begin{array}{l}\text { Min }-.47 \\
\text { Max } 2.76\end{array}$ & -.2043 & .80382 & 0.630 \\
\hline Head monthly income above TK $15,000(0,1)$ & & 0.09 & 0.287 & 0.799 \\
\hline Spouse has monthly income $(0,1)$ & & 0.045 & 0.190 & 0.070 \\
\hline Remittance (US\$ per month; conversion 1 US $\$=$ TK. 84 as of Nov 2018) & & 28.85 & 112.413 & 0.806 \\
\hline Social capital & $\begin{array}{l}\operatorname{Min}-1.18 \\
\operatorname{Max} 4.56\end{array}$ & .0117 & 1.43241 & 0.625 \\
\hline Member of a professional association $(0,1)$ & & 0.19 & 0.395 & 0.740 \\
\hline Member of a cultural/sports association $(0,1)$ & & 0.12 & 0.329 & 0.769 \\
\hline Member of a religious group/association $(0,1)$ & & 0.32 & 0.467 & 0.478 \\
\hline Member of an NGO group/association $(0,1)$ & & 0.43 & 0.495 & 0.249 \\
\hline Physical capital & $\begin{array}{l}\text { Min }-2.00 \\
\text { Max } 9.21\end{array}$ & .0073 & 2.09427 & 0.790 \\
\hline Has two or more house $(0,1)$ & & 0.06 & 0.246 & 0.476 \\
\hline Has bicycle/rickshaw $(0,1)$ & & 0.19 & 0.395 & 0.527 \\
\hline Has motorbike $(0,1)$ & & 0.07 & 0.254 & 0.517 \\
\hline Has TV $(0,1)$ & & 0.07 & 0.250 & 0.654 \\
\hline Has radio $(0,1)$ & & 0.65 & 0.479 & 0.250 \\
\hline Has two or more mobile phone $(0,1)$ & & 0.49 & 0.501 & 0.575 \\
\hline Has smartphone $(0,1)$ & & 0.25 & 0.436 & 0.709 \\
\hline Natural capital & $\begin{array}{l}\text { Min }-1.38 \\
\text { Max } 13.88\end{array}$ & .0011 & 1.65914 & 0.653 \\
\hline Tropical Livestock Unit (scale score) & & 1.366 & 1.664 & 0.690 \\
\hline Area of farmland (acres) & & 0.093 & 0.243 & 0.855 \\
\hline Area of homestead (including ponds) (acres) & & 0.085 & 0.106 & 0.671 \\
\hline Adaptive Capacity & $\begin{array}{l}\operatorname{Min}-2.66 \\
\operatorname{Max} 8.97\end{array}$ & .0000 & 2.09373 & - \\
\hline
\end{tabular}

Human capital: Eigenvalue of the first principal component $(\mathrm{PC} 1)=1.399$; total variance explained by $\mathrm{PC} 1=34.980 \%$ (age of spouse was excluded from analysis as $>98 \%$ were up to 64 years)

Financial capital: Eigenvalue $\mathrm{PC} 1=1.293$; total variance explained by $\mathrm{PC} 1=43.101 \%$

Social capital: Eigenvalue $\mathrm{PC} 1=1.428$; total variance explained by $\mathrm{PC} 1=35.709 \%$

Physical capital: Eigenvalue PC1 2.096; total variance explained by PC1 = 29.936\% (excluded: no mobile, one mobile, brick house, sanitary latrine, tube well, easy bike)

Natural capital: Eigenvalue PC1 = 1.658; total variance explained by $\mathrm{PC} 1=55.252 \%$

Adaptive capacity: $\mathrm{PC} 1$ Eigenvalue $=2.093$; variance explained by $\mathrm{PC} 1=41.868 \%$

Child dependency ratio = total number of children $(<15$ years old $)$ in the household divided by the total number of working age adults in the household multiplied by 100 . Child dependency ratio was preferred over a dependency ratio as we did not have data on the number of members $\geq 65$ years of age

Remittance had the highest weighting (0.806) in the financial capital (FC) index, the second highest (0.799) being head's monthly income of TK. $>15,000$. About $5 \%$ households had income from spouses, but this indicator had a very low (0.07) contribution to the FC index.
Over $40 \%$ households had NGO memberships, but this indicator had the lowest weighting $(0.249)$ to the social capital (SC) index. Membership in religious groups had the second lowest weight $(0.478)$. Very few were members of professional and cultural/sports 
Fig. 8 Scatterplot showing the spread of AC and its correlation with the FCSs

Fig. 9 Mean of the assets and AC indices within the unacceptable and acceptable categories (HC=Human Capital; $\mathrm{NC}=$ Natural Capital;

$\mathrm{PC}=$ Physical Capital; $\mathrm{SC}=$ Social Capital; FC=Financial Capital; $\mathrm{AC}=$ Adaptive Capacity)

Fig. 10 Mean AC index scores of occupation groups within the unacceptable and acceptable categories

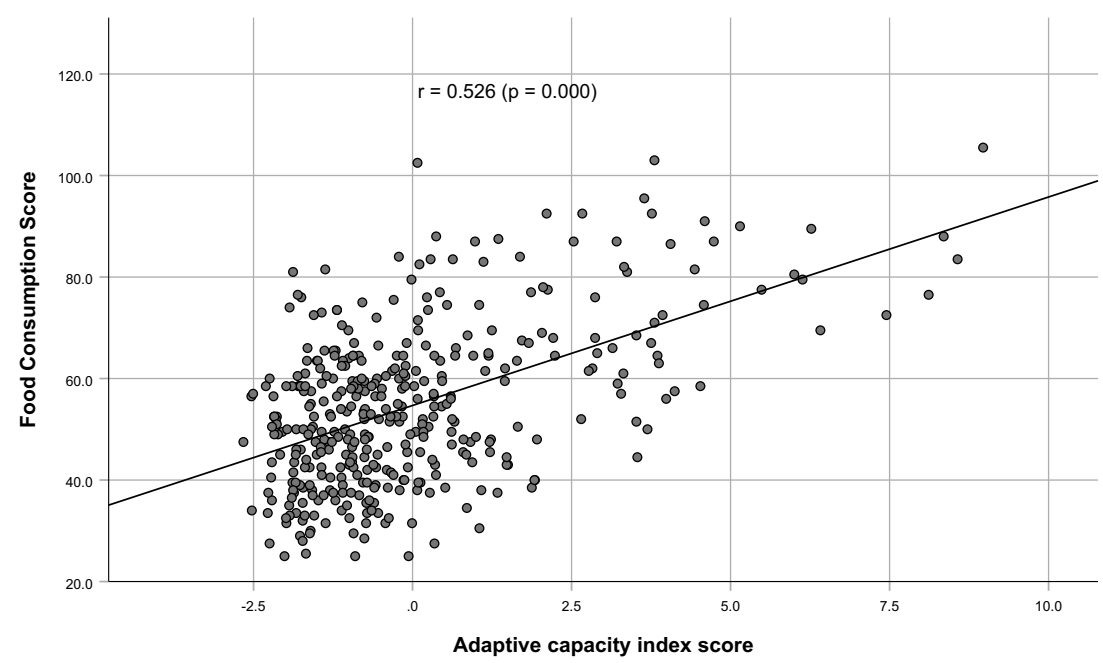

Food access

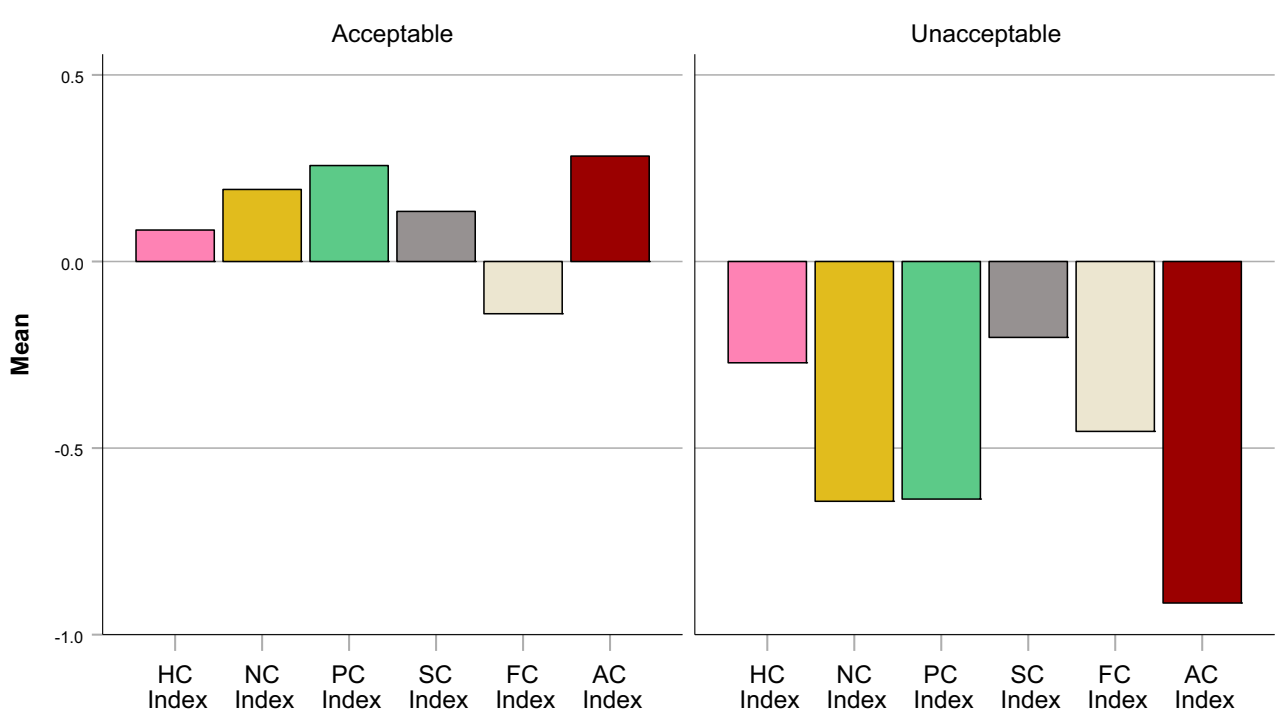

Food access

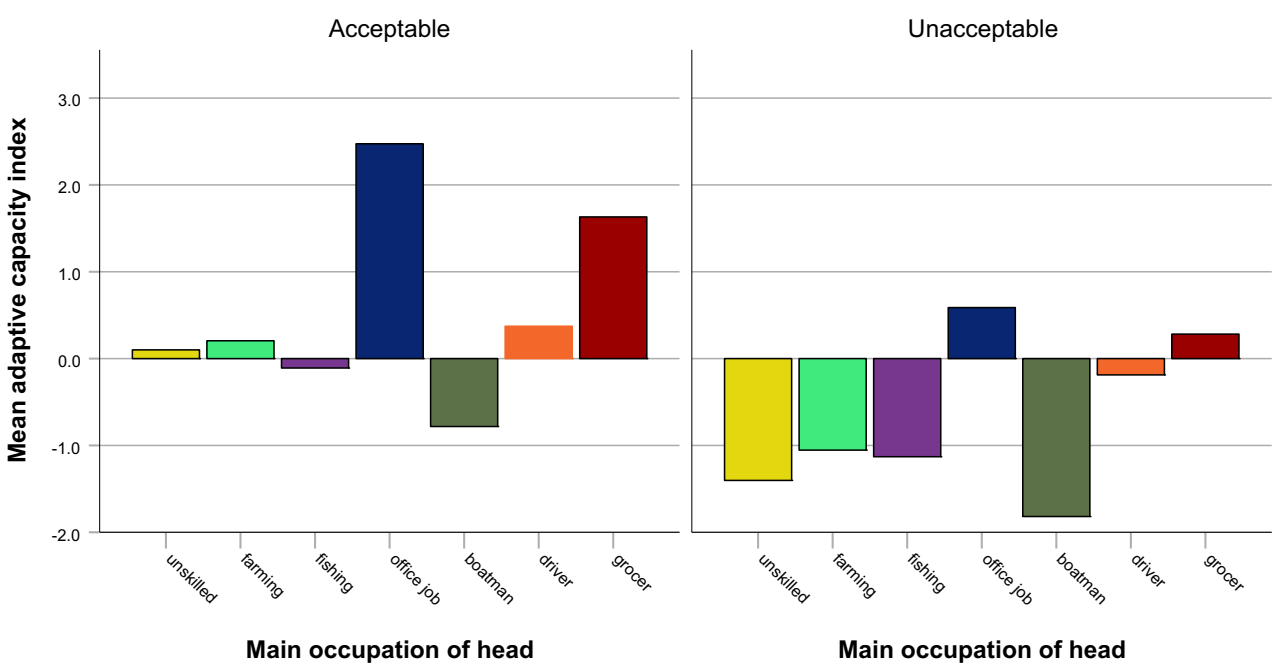


associations, with the latter contributing the most $(0.769)$ to the SC index.

Only $6 \%$ of the households had two or more houses, but it had the second lowest weight $(0.476)$ within the physical capital (PC) index. The ownership of motorbike and TV was also very low, with the latter having the second highest weight (0.654). A quarter of the households had smartphones and this indicator had the highest loading $(0.709)$ on the PC index. The lowest weight $(0.250)$ was for radio ownership.

Around $65 \%$ of the sampled households had no farmlands at all. Within the rest, land ownership ranged from 0.01 acre to 2.8 acres only. This indicator had the highest loading $(0.855)$ on the Natural Capital (NC) index, followed by livestock and homesteads.

As expected, all the asset indices had positive contributions to the $\mathrm{AC}$ index, with the highest coming from the PC index and the lowest from the $\mathrm{HC}$ index (Table 6). The weightings for the other indices were very similar.

Exploratory analyses revealed a strong positive correlation between the Food Consumption Scores (FCSs) and the AC of the sampled households (Fig. 8).

Disaggregated analysis of the five asset indices and the AC index between the unacceptable and acceptable food access categories are shown in Fig. 9. All the asset indices, and thus the $\mathrm{AC}$ index, were considerably lower within the unacceptable category.

Further disaggregated analysis of the $\mathrm{AC}$ scores according to head's main occupation is shown in Fig. 10. Unskilled, farmer, and fisher groups had very low $\mathrm{AC}$, but those within the acceptable category, especially unskilled and farmer groups, looked slightly better-off. Boatman had the least AC of all the occupation groups, but those within the unacceptable category had lower AC than those in the acceptable category. Drivers within the unacceptable category had less AC. The grocer group within the acceptable category showed significantly higher $\mathrm{AC}$ than those within the unacceptable category. The picture was the same for the office job holders.

\subsection{Vulnerability}

The spread of the vulnerability index scores vis-à-vis the Food Consumption Scores (FCSs) are shown in Fig. 11. A higher score indicates a higher vulnerability of a household, and vice versa. Since the vulnerability scores were created by deducting the AC scores from the ES scores, a positive vulnerability score would indicate that the household concerned had insufficient $\mathrm{AC}$ to address their ES to a hazard. All the three vulnerability indices showed strong negative correlations with the FCSs.

Disaggregation of the vulnerability scores between the unacceptable and acceptable categories revealed that the households within the former category had considerably higher vulnerabilities to all the three hazards compared to
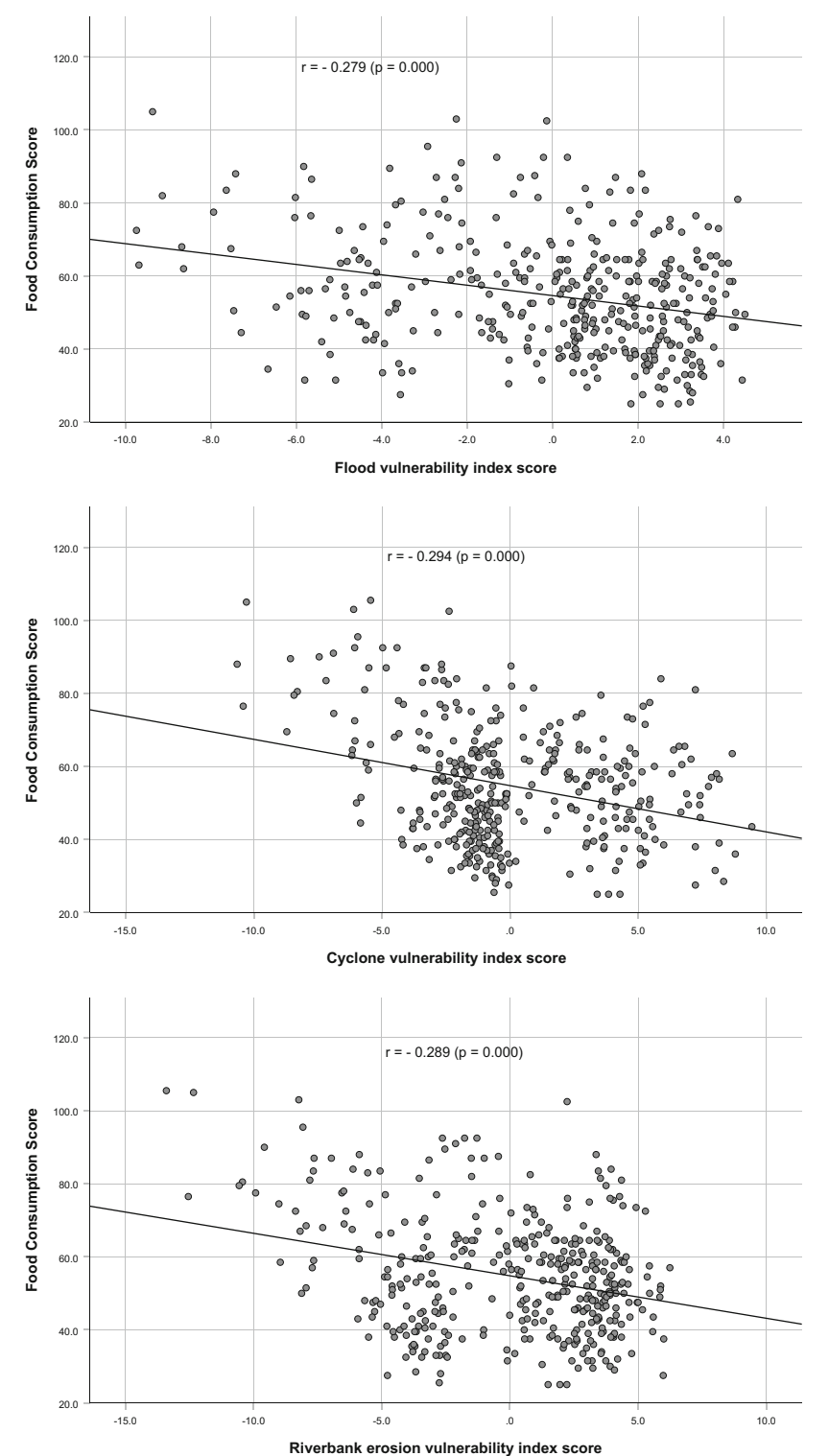

Fig. 11 Scatterplots showing the spread of the vulnerability index scores and their correlations with the FCSs

the households within the latter category (Fig. 12). The variation in flood vulnerability was the highest, followed by the variations in cyclone and riverbank erosion vulnerabilities. This finding indicated that, whilst, all the vulnerabilities might have links with unacceptable food access, flood vulnerability might have the strongest link.

Further disaggregation according to occupation groups revealed clear distinction between the acceptable and unacceptable categories (Fig. 13). Grocers within the unacceptable category showed higher flood vulnerability scores than those within the acceptable category. The same was found for the driver, farmer, and unskilled groups. It was likely, therefore, that flood vulnerability would have a link with unacceptable food access within these groups. 
Fig. 12 Mean vulnerability index scores within the acceptable and unacceptable categories
Fig. 13 Mean vulnerability index scores of occupation groups within the acceptable and unacceptable categories
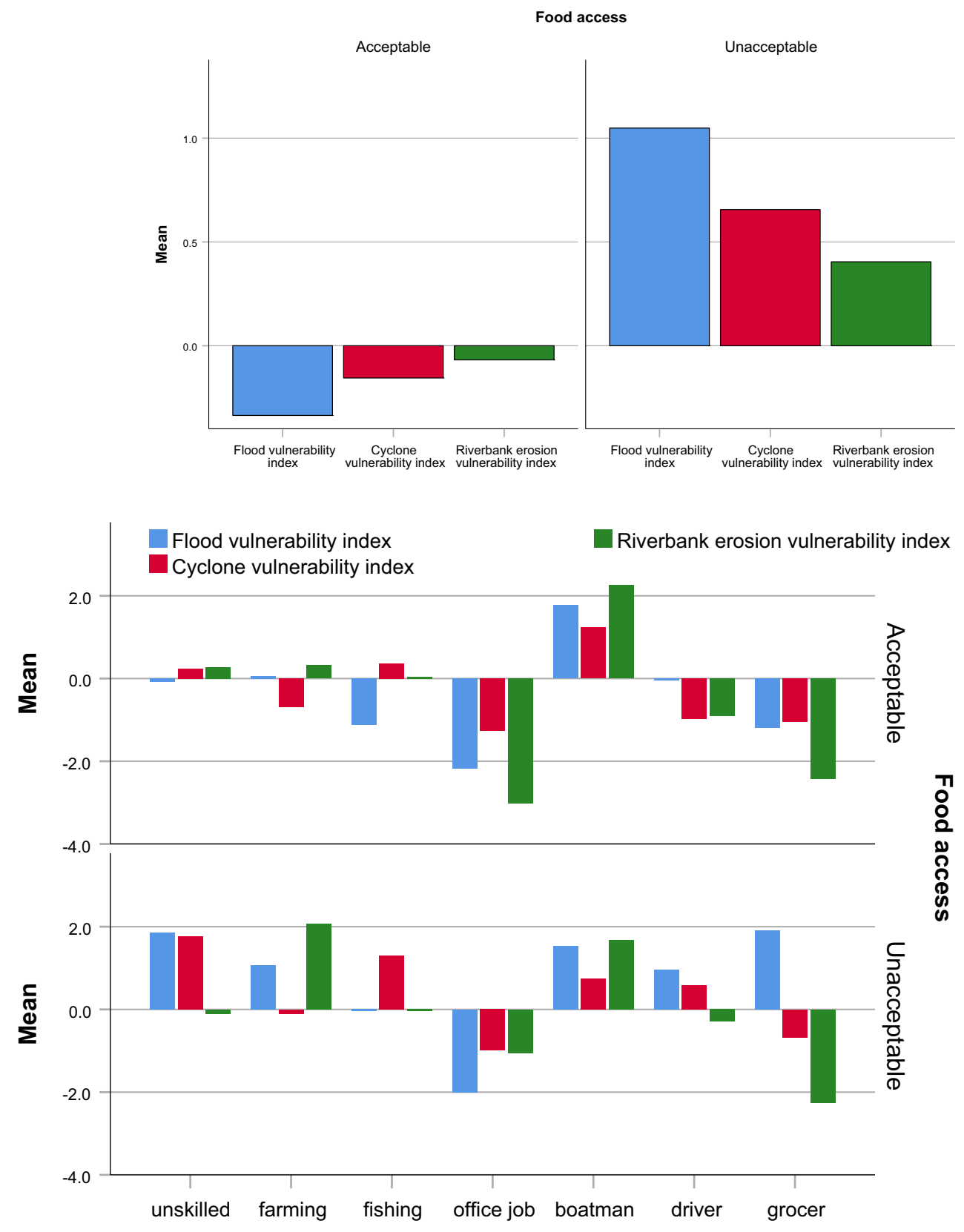

Main occupation of head

\subsection{Effects of exposure-sensitivity (ES) and vulnerability on food access}

To confirm if ES had an effect on household food access, we fitted all the three ES variables into a generalised linear regression model (eq. 4) by taking the Food Consumption Scores (FCSs) as the dependent variable. The results (Table 7) confirmed that none of the ES variables had any significant effect on food access. The non-significant omnibus test statistic indicated that the model with the explanatory ES variables included was not a significant improvement over the baseline model. Therefore, we did not proceed to further analyses by disaggregating the FCS into a binary variable.

The results of the generalised regression model with the vulnerability indices included as explanatory variables indicated that all the variables had significant negative effects on food access (Table 8). The significant $(p \leq 0.001)$ omnibus test statistics suggested that the model was plausible.

To confirm if the vulnerability variables could push a household below the acceptable threshold of food consumption (as per WFP 2008), we ran a binary logistic regression (equations 5and 6) by treating the FCS as a binary variable 
Table 7 Effects of the ES variables on the household Food Consumption Scores

\begin{tabular}{lllll}
\hline Parameter & Coeff. (B) & Std. Error & Wald & Sig. \\
\hline (Intercept) & 53.975 & .7773 & 4822.469 & .000 \\
$\mathrm{ES}_{\mathrm{fl}}$ & .278 & .3030 & .842 & .359 \\
$\mathrm{ES}_{\mathrm{cycl}}$ & .160 & .2478 & .419 & .518 \\
$\mathrm{ES}_{\mathrm{re}}$ & .069 & .2613 & .070 & .791 \\
\hline
\end{tabular}

Model: Genearlised linear regression model with Identity link function; Estimation: Maximum Likelihood

Omnibus Test: Likelihood Ratio Chi-sq. $1.312(p=0.726)$

For missing values listwise deletion was used ( $N=417$ in the model)

$\mathrm{ES}_{\mathrm{fl}}, \mathrm{ES}_{\mathrm{cycl}}$, and $\mathrm{ES}_{\mathrm{re}}$ refer to the exposure-sensitivity to flood, cyclone and river erosion, respectively

Table 8 Effects of the vulnerability variables on the household Food Consumption Scores

\begin{tabular}{lllll}
\hline Parameter & Coeff. (B) & Std. Error & Wald & Sig. \\
\hline (Intercept) & 54.769 & .7374 & 5516.861 & .000 \\
$\mathrm{~V}_{\text {fl }}$ & -1.026 & .2504 & 16.782 & $\mathbf{. 0 0 0}$ \\
$\mathrm{V}_{\text {cycl }}$ & -.740 & .2179 & 11.529 & $\mathbf{. 0 0 1}$ \\
$\mathrm{V}_{\text {re }}$ & -.803 & .1960 & 16.783 & $\mathbf{. 0 0 0}$ \\
\hline
\end{tabular}

Model: Genearlised linear regression model with Identity link function; Estimation: Maximum Likelihood

Omnibus Test: Likelihood Ratio Chi-sq. 71.795 ( $p=0.000)$

For missing values listwise deletion was used ( $N=398$ in the model)

$\mathrm{V}_{\mathrm{fl}}, \mathrm{V}_{\text {cycl }}$, and $\mathrm{V}_{\mathrm{re}}$ refer to the vulnerability to flood, cyclone, and riverbank erosion, respectively

(FCS $\leq 42.0=$ unacceptable food access and FCS $\geq 42.5=$ acceptable food access). In this model we treated unacceptable as the response (coded as 1.0) and the acceptable as the reference category (coded as 0.0 ).

The results (Table 9) indicated that flood vulnerability was the only variable having a significant effect. The odds ratios (exponential of Beta) suggested that, given the other

Table 9 Effects of the vulnerability variables on the likelihood of a household having an unacceptable level of food access

\begin{tabular}{llllll}
\hline Parameter & Coeff. (B) & Std. Error & Wald & Sig. & Exp(B) \\
\hline (Intercept) & -1.275 & .1294 & 97.095 & 0.000 & .279 \\
$\mathrm{~V}_{\mathrm{fl}}$ & .159 & .0501 & 10.022 & $\mathbf{0 . 0 0 2}$ & 1.172 \\
$\mathrm{~V}_{\text {cycl }}$ & .019 & .0368 & .275 & 0.600 & 1.019 \\
$\mathrm{~V}_{\text {re }}$ & .009 & .0347 & .064 & 0.800 & 1.009 \\
\hline
\end{tabular}

Model: Genearlised linear regression model with Logit link function; Estimation: Hybrid

Omnibus Test: Likelihood Ratio Chi-sq. $15.210(p=0.002)$

For missing values listwise deletion was used $(\mathrm{N}=398$ in the model)
Table 10 Interaction effects of flood vulnerability and household head's occupation on the odds of a household having unacceptable food access

\begin{tabular}{llllll}
\hline Parameter & $\mathrm{B}$ & Std. Error & Wald & Sig. & Exp(B) \\
\hline (Intercept) & -1.321 & .1398 & 89.250 & .000 & .267 \\
Unskilled $* \mathrm{~V}_{\mathrm{fl}}$ & .251 & .0971 & 6.690 & $\mathbf{. 0 1 0}$ & 1.285 \\
Farmer $* \mathrm{~V}_{\mathrm{fl}}$ & .182 & .0960 & 3.605 & .059 & 1.200 \\
Fisherman $* \mathrm{~V}_{\mathrm{fl}}$ & .111 & .0901 & 1.504 & .220 & 1.117 \\
Office $* \mathrm{~V}_{\mathrm{fl}}$ & .075 & .1827 & .167 & .683 & 1.078 \\
Boatman $* \mathrm{~V}_{\mathrm{fl}}$ & -.138 & .1667 & .685 & .408 & .871 \\
Driver $* \mathrm{~V}_{\mathrm{fl}}$ & .279 & .2007 & 1.933 & .164 & 1.322 \\
Grocer $* \mathrm{~V}_{\mathrm{fl}}$ & .543 & .2302 & 5.557 & $\mathbf{. 0 1 8}$ & 1.720 \\
\hline
\end{tabular}

Model: Genearlised linear regression model with Logit link function; Estimation: Hybrid

Omnibus Test: Likelihood Ratio Chi-sq. 89.250 ( $p=0.000)$

For missing values listwise deletion was used ( $N=398$ in the model)

vulnerability variables constant, the odds of a household with a flood vulnerability score of 1.0 to fall within the unacceptable category would be around 1.17 times (or 17\%) higher than that of a household with a zero flood vulnerability score (as per eq. 6). The significant $(p \leq 0.01)$ omnibus test statistics indicated that the model was plausible.

To identify which occupational groups were likely to have unacceptable food access due to floods, we estimated the interaction effects of flood vulnerability and the household heads' main occupation. The results (Table 10) indicated that grocers and unskilled labourers were significantly more likely to be affected. Of this, grocers appeared to be the worst affected in terms of the corresponding odds ratio.

\section{Discussion and conclusions}

In this research we aimed to investigate if climatic hazards could affect the food access of households resident in hazard-prone areas of developing country deltas and who was likely to be at risk and why. To achieve these aims we applied an analytical framework (section 2) consisting of four constructs: exposure-sensitivity (ES), adaptive capacity (AC), vulnerability (V), and food access (measured as Food Consumption Scores). Accordingly, we explored, using data from a hazard-prone delta zone in Bangladesh, if there was an effect of ES on food access, an effect of V (ES-AC) on food access, and an effect on food access of the interactions between $V$ and households heads' main occupation.

Our regression analysis confirmed that ES did not have a direct effect on food access (Table 7). Unlike ES, however, we found significant negative effects of all the three $\mathrm{V}$ indices - flood, cyclone, and riverbank erosion - on food access (Table 8). This confirmed that, rather than ES alone, it was the combined effects of both the ES and AC that hampered food access. 
However, by considering food access as a binary variable unacceptable and acceptable - we found that flood vulnerability was the only variable that could reduce a household's food access below an acceptable level (Table 9). These findings indicate that some hazards can be more significant than the others, and therefore, vulnerability analyses and interventions aimed at improving household food access in deltas need to be location- and hazardspecific, rather than general (Vincent 2007).

Disaggregated analyses of ES and AC can help explain why flood had such an effect. The households within the acceptable category had considerably lower flood ES (Fig. 6), but much higher AC (Fig. 9). In contrast, the households within the unacceptable category had higher flood ES (Fig. 6), but significantly lower AC (Fig. 9). The combined effects of these two variables, therefore, made the households within the unacceptable category significantly vulnerable to floods. Moreover, unlike cyclone and riverbank erosion, the damages inflicted by floods can be long-lasting. The ES indicators within the flood index (Table 5) suggest that in the current study area such damage occurred mainly through the loss of livestock (highest weight), disease attacks (second highest weight) and damage to houses/household goods (third highest weight). Disease attack is particularly noteworthy. As shown in Table 5, across the three hazards, disease attack had the highest weight in the flood ES and the lowest in the riverbank ES. Diseases can have very long-lasting consequences on a household, such as increased financial stress due to burden of care and reduced supply of labour due to illness and death. This, in turn, could worsen a household's ability to access food (de Waal and Whiteside 2003). These findings indicate the need for food security interventions in deltas to move beyond agricultural focus and adopt such measures as protecting livestock and houses as well as preventing disease outbreaks following a hazard.

Regarding livelihood groups, our finding contradicts the broad generalisation in the recent UN reports (FAO et al. 2018; FAO 2016) that climatic hazards would particularly affect the food security of 'natural-resource-based' livelihoods. The effects of flood vulnerability on the farmer- and fishermen-headed households in our study were not significant (Table 10). In contrast, floods significantly affected the food access of two non-natural-resource-based livelihoods, including small grocers and unskilled labourers (e.g. day labourers and rickshaw pullers). Such observations raise the need to make food security interventions in developing country deltas 'all-inclusive' by considering all livelihood groups. Such a requirement is rarely specified in the current literature on climate and food security, including the recent state of the world's food security reports (FAO et al. 2018; FAO 2016).

Disaggregated analyses shed light as to why the grocers and unskilled labourers were more likely to have unacceptable food access. In this case as well, a combined effect of ES and AC can be seen. The grocers within the unacceptable category had much higher flood ES (Fig. 7), but much lower AC (Fig. 10) compared to the grocers within the acceptable category. The same pattern can be observed for the unskilled.

Whilst, both ES and AC were found important in explaining household food access, AC appeared to be more important. Exploratory analyses showed that none of the ES variables was correlated with the Food Consumption Scores (Fig. 5). Unlike ES however, AC had a strong positive correlation (Fig. 8). Moreover, the ES scores did not show a clear pattern of variation between the acceptable and unacceptable categories. For example, the households within the acceptable category had higher ES to riverbank erosion and cyclones (Fig. 6). Similarly, flood ES was higher among the office job holders and boatmen within the acceptable category (Fig. 7). However, what was common among all the households within the unacceptable category was that they had much lower AC scores compared to those in the acceptable category (Figs. 9 and 10). Higher AC therefore explained why some households, e.g. within the office job holder group, managed to maintain an acceptable level of food consumption despite having higher ES. Since, AC is conceptualised in this research and the wider literature (see the references in Table 1) as a function of assets, it can be inferred that efforts towards improving food access in hazard-prone deltas would require more emphasis on building household assets, alongside preventing hazard exposure and damages.

Our study provides two important lessons for such an assetbuilding approach. First, it shows that, all the five types of assets considered in this study are important for AC, although their relative importance may vary. For instance, although physical capital had the highest contribution to the AC index, the other assets including social, financial, natural, and human capitals were almost equally important (Table 6). Therefore, the said asset-building approach needs to be holistic by going beyond traditional income-generation or cash support measures and include such less-recognised measures as improving vulnerable peoples' organisational capacity and literacy.

Second, within each asset type, the emphasis on specific assets may vary (Table 6). Within the physical capital index, the possession of smart phones and multiple houses had the highest weights. Not only are these manifestations of a household's wealth and status (which can help them access other forms of capital), but also are crucial for climate-related AC (Table 1). Smart phones, for instance, can help people access hazard early waring information, sometimes live through Internet connections. TV (the indicator with the second highest weight within physical capital) can also enhance access to such information. More mobile phones (third highest weight within physical capital) can mean more household members being able to access weather and early warning information.

Within financial capital, the highest weighting was for remittance (Table 6). Some households in our sample had members working overseas, especially in the Middle-Eastern countries. This study shows the importance of the money they send back 
home. The next highest weighting was for the head's monthly income of TK. $>15,000$. Improving the financial capital of vulnerable households, therefore, would require promoting highincome and off-farm jobs, as found in other studies (see Table 1).

Similarly, membership of cultural/sports and professional organisations was quite important within the social capital index (Table 6). Membership in NGO groups, however, had the least contribution, probably because NGOs operating in the region mostly provide micro-finance services, the impacts of which was found minimal in a previous study (Jordan 2015). Improving vulnerable households' social capital, therefore, would require greater emphasis on supporting and strengthening local institutions.

For natural capital, ownership of farmlands had the highest weight (Table 6), the importance of which is widely recognised in the literature (see Table 1), implying the need for land distribution interventions to support the landless. Additionally, the secondary and above level education of household heads and spouses had the highest effects on human capital, indicating the need for promoting higher education in deltaic areas.

By pulling together all these findings, we can develop a holistic, livelihood-oriented, and asset-based framework of interventions for improving food access in climatic hazard-prone areas of developing country deltas. An example of how such an intervention may look like is provided in Fig. 14, by taking the current study area as a case. This framework illustrates that an intervention that aims to improve food security in developing country deltas solely by addressing the risks to agricultural (fisheries) production is bound to be inadequate.

Some limitations of this study provide lessons for further studies. We could analyse the effects of hazard vulnerability on household Food Consumption Scores (FCSs) only. Although FCS is a well-tested and methodologically robust proxy indicator of food access, it is criticised as being weaker in capturing the quality dimension of food access (e.g. micronutrient adequacy) (Leroy et al. 2015). Therefore, it may be useful to test our models for other food access indicators (Leroy et al. 2015).

Additionally, we had to drop several important indicators such as the ownership of brick houses, sanitary latrine, tube well; and female-headed households - as there was inadequate data variability on these indicators for PCA to be effective. A larger sample covering wider regions would have helped overcome this problem. Moreover, there are other indicator variables of interest, e.g. income diversification, household savings, and proportion of income coming from natural-resource-based occupations (e.g. agriculture and fisheries). Likewise, we could only include in our analyses the indicators of 'linking' social capital, although 'bridging' and 'bonding' social capital may be important as well (Jordan 2015; Vincent 2007). Due to data limitations, we could not verify the effects of institutional and policy factors on hazard vulnerability and food access. Relevant indicators - such as free or subsidised input distributions, public works programs, and

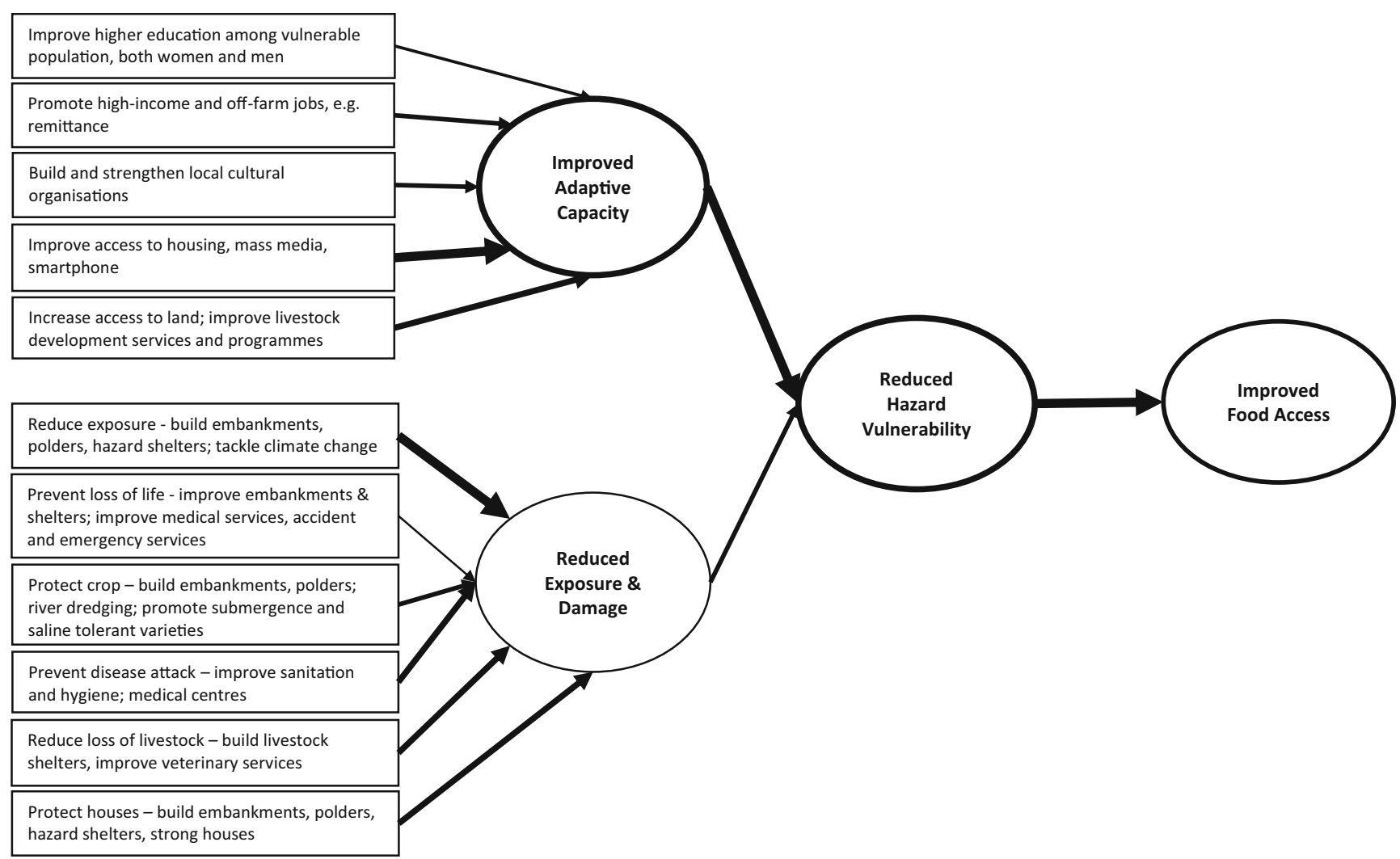

Fig. 14 An example of a holistic framework for improving household food access in climatic hazard-prone deltas (note: thicker lines indicate higher importance and urgency) 
grain reserve management or food pricing policies (Devereux 2007) - may be worth investigating. In addition, in any adaptive system having a human component, learning is an important factor. Therefore, further studies could consider this indicator.

Because of the cross-sectional nature of this research, it provides only a snapshot in time. Such an approach has limitations, e.g. it cannot explain "chronic" (persistent, long-lasting) and "seasonal" food insecurities as well as the shifts in livelihood assets over time due to hazard impacts. Future studies could use a longitudinal or historical approach combining time series or panel data.

Acknowledgements We thank all the individuals and organisations who have supported this study. We are extremely grateful to the households in Hatiya, Bangladesh, for providing data for this research. We also thank the two anonymous reviewers for their rigorous review of the manuscript and valuable comments. The study was made possible through Nottingham Trent University (NTU) funding support and a British Commonwealth scholarship.

\section{Compliance with ethical standards}

Conflict of interest The authors declare that they have no conflict of interest.

Open Access This article is distributed under the terms of the Creative Commons Attribution 4.0 International License (http:// creativecommons.org/licenses/by/4.0/), which permits unrestricted use, distribution, and reproduction in any medium, provided you give appropriate credit to the original author(s) and the source, provide a link to the Creative Commons license, and indicate if changes were made.

\section{References}

Abdrabo, M. A., Hassaan, M. A., \& Selmy, A. R. N. (2015). Economic valuation of sea level rise impacts on agricultural sector in northern governorates of the Nile Delta. Low Carbon Economy, 6, 51-63.

Adger, W. N. (1999). Social vulnerability to climate change and extremes in coastal Vietnam. World Development, 27(2), 249-269.

Adger, W. N. (2003). Social capital, collective action, and adaptation to climate change. Economic Geography, 79(4), 387-404.

Adger, W. N., \& Kelly, P. M. (1999). Social vulnerability to climate change and the architecture of entitlements. Mitigation and Adaptation Strategies for Global Change, 4(3), 253-266.

Agriesti, A. (2007). An introduction to categorical data analysis (2nd ed.). New Jersey: Wiley.

Alam, M.R. (2012). Climate change and its impact on health and livelihood within Hatiya Island of Bangladesh. Journal of agroforestry and environment, 6 (2): 13-16, 2012.

Allison, E. H., Perry, A. L., Badjeck, M.-C., Adger, N. W., Brown, K., Conway, D., et al. (2009). Vulnerability of national economies to the impacts of climate change on fisheries. Fish and Fisheries, 10, 173-196.

AMS (American Meteorological Society). (1998). Tropical cyclones and global climate change. A Post-IPCC Assessment. Bulletin of the American Meteorological Society, 79, 19-38.

Anthony, E. J., Brunier, G., Besset, M., Goichot, M., Dussouillez, P., \& Nguyen, V. L. (2015). Linking rapid erosion of the Mekong River delta to human activities. Scientific Reports, 5, 14745. https://doi. org/10.1038/srep14745.

Antwi-Agyei, P., Dougill, A.J., Fraser, E.D.G., \& Stringer, L.C. (2012). Characterising the nature of household vulnerability to climate variability: Empirical evidence from two regions of Ghana.
Environment, Development and Sustainability, https://doi.org/10. 1007/s10668-012-9418-9.

Arto, I., García-Muros, X., Cazcarro, I., González-Eguino, M., Markandya, A., \& Hazra, S. (2019). The socioeconomic future of deltas in a changing environment. Science of the Total Environment, 648(2019), 1284-1296.

Banglapedia (2015). National Encyclopaedia of Bangladesh [Online]. Available at: http://en.banglapedia.org/index.php?title=Hatiya Upazila (accessed 29/11/2018).

BBS. (Bangladesh Bureau of Statistics). (2011). Statistical yearbook of Bangladesh. Dhaka: Bangladesh Bureau of Statistics.

BBS. (Bangladesh Bureau of Statistics). (2013). District statistics 2011 Noakhali. Dhaka: Bangladesh Bureau of Statistics.

BBS. (Bangladesh Bureau of Statistics). (2017). Statistical yearbook of Bangladesh 2017. Dhaka: Bangladesh Bureau of Statistics.

Bhattacharjee, K., \& Behera, B. (2018). Determinants of household vulnerability and adaptation to floods: Empirical evidence from the Indian state of West Bengal. International Journal of Disaster Risk Reduction, 31, 758-769.

Chambers, R., \& Conway, G. (1992). Sustainable rural livelihoods: Practical concepts for the 21 st century. In IDS discussion paper 296. Sussex: Institute of Development Studies.

Clarke, D., Lazar, A. N., Saleh, A. F. M., \& Jahiruddin, M. (2018). Prospects for agriculture under climate change and soil salinisation. In R. J. Nicholls et al. (Eds.), Ecosystem Services for Well-being in deltas (pp. 447-467). Switzerland: Palgrave Macmillan.

Collins, J. (2014). A rising tide in Bangladesh: Livelihood adaptation to climate stress. Australian Geographer, 45, 289-307.

Córdova, A. (2008). Methodological Note: Measuring Relative Wealth using Household Asset Indicators. Americas Barometer Insights, 2008 (No. 6). Available at: https://www.vanderbilt.edu/lapop/ insights/I0806en v2.pdf (accessed 15/10/2018).

Cutter, S. L., Emrich, C. T., Webb, J. J., \& Morath, D. (2009). Social vulnerability to climate variability hazards: A review of the literature. Final report to Oxfam America. Columbia: Hazards and Vulnerability Research Institute, University of South Carolina.

Dar, M. H., Chakravorty, R., Waza, S. A., Sharma, M., Zaidi, N. W., Singh, A. N., et al. (2017). Transforming rice cultivation in flood prone coastal Odisha to ensure food and economic security. Food Security, 9(4), 711-722.

Das, D. (2017). Tropical cyclones and coastal communities: The dialectics of social and environmental change in the Sundarban delta. Journal of the Indian Ocean Region, 13(2), 257-275.

Dasgupta, S., Laplante, B., Meisner, C., Wheeler, D., \& Yan, J. (2009). The impact of sea level rise on developing countries: A comparative analysis. Climatic Change, 93, 379-388.

Dasgupta, S., Laplante, B., Murray, S., \& Wheeler, D. (2011). Exposure of developing countries to sea-level rise and storm surges. Climatic Change, 106, 567-579.

de Waal, A., \& Whiteside, A. (2003). New variant famine: AIDS and food crisis in southern Africa. The Lancet, 362(9391), 1234-1237.

Demeke, A. B., Keil, A., \& Zeller, M. (2011). Using panel data to estimate the effect of rainfall shocks on smallhers food security and vulnerability in rural Ethiopia. Climatic Change, 108(1-2), 185-206.

Devereux, S. (2001). Sen's Entitlement Approach: Critiques and Countercritiques. Oxford Development Studies, 29(3), 245-263.

Devereux, S. (2007). The impact of droughts and floods on food security and policy options to alleviate negative effects. Agricultural Economics, 37(1), 47-58.

DFID. (1999). Sustainable livelihoods guidance sheets. London, UK: Department for International Development.

Dilley, M., \& Boudreau, T. E. (2001). Coming to terms with vulnerability: A critique of the food security definition. Food Policy, 26(3), 229-247.

van Driel W.F., Bucx, T., Makaske, A., van de Guchte C., van der Sluis T., Biemans, H., et al. (2015). Vulnerability assessment of deltas in transboundary river basins. Delta Alliance contribution to the 
Transboundary water assessment program, river basins assessment. Delta Alliance report 9. Delta Alliance international, Wageningen Delft, the Netherlands.

Duncan, J. M., Tompkins, E. L., Dash, J., \& Tripathy, B. (2017). Resilience to hazards: Rice farmers in the Mahanadi Delta, India. Ecology and Society, 22(4), 3.

Ericksen, P., Thornton, P., \& Notenbaert, A. (2011). Mapping hotspots of climate change and food insecurity in the global tropics. Nairobi: International Livestock Research Institute.

Ericson, J. P., Vörösmarty, C. J., Dingman, S. L., Ward, L. G., \& Meybeck, M. (2006). Effective Sea-level rise and deltas: Causes of change and human dimension implications. Global and Planetary Change, 50(1-2), 63-82.

Esham, M., Jacobs, B., Rosairo, H. S. R., \& Siddighi, B. B. (2018). Climate change and food security: A Sri Lankan perspective. Environment, Development and Sustainability, 20(3), 1017-1036.

FAO. (1996). Rome Declaration on World Food Security and World Food Summit Plan of Action. World Food Summit, 13-17 November, 1996, Rome.

FAO, IFAD \& WFP. (2015). The State of Food Insecurity in the World 2015. Meeting the 2015 international hunger targets: Taking stock of uneven progress. Rome: FAO.

FAO, IFAD, UNICEF, WFP \& WHO. (2017). The State of Food Security and Nutrition in the World 2017. Building resilience for peace and food security. Rome: FAO.

FAO, IFAD, UNICEF, WFP \& WHO. (2018). The State of Food Security and Nutrition in the World 2018. Building climate resilience for food security and nutrition. Rome: FAO.

FAO. (2016). The state of food and agriculture 2016: Climate change, agriculture and food security. Rome.

Filmer, D., \& Pritchett, L. H. (2001). Estimating wealth effects without expenditure data - or tears: An application to educational enrolments in states of India. Demography, 38(1), 115-132.

Hahn, M. B., Riederer, A. M., \& Foster, S. O. (2009). The livelihood vulnerability index: A pragmatic approach to assessing risks from climate variability and change - A case study in Mozambique. Global Environmental Change, 19, 74-88.

Haque, A., \& Nicholls, R. (2018). Floods and the Ganges-BrahmaputraMeghna Delta. In R. J. Nicholls et al. (Eds.), Ecosystem Services for Well-being in deltas (pp. 147-159). Switzerland: Palgrave Macmillan.

Hassan, S. M. T., Syed, M. A., \& Mamnun, N. (2017). Estimating erosion and accretion in the coast of Ganges-Brahmaputra-Meghna delta in Bangladesh. In Paper presented at the $6^{\text {th }}$ international conference on Water \& Flood Management (ICWFM-2017), 4-6 march 2017. Dhaka: Bangladesh.

Hughes, S., Yau, A., Max, L., Petrovic, N., Davenport, F., Marshall, M., et al. (2012). A framework to assess national level vulnerability from the perspective of food security: The case of coral reef fisheries. Environmental Science \& Policy, 23, 95-108.

IPCC. (2007). Climate change 2007: Impacts, adaptation and vulnerability: Contribution of working group II to the fourth assessment report of the intergovernmental report on climate change. Cambridge: Cambridge University Press.

Islam, M., Huda, M., \& Islam, S. M. D. (2016). Changing cropping pattern in disaster prone region of Bangladesh: A case study. Jahangirnagar University Environment Bulletin, 5, 25-36.

Jordan, J. C. (2015). Swimming alone? The role of social capital in enhancing local resilience to climate stress: A case study from Bangladesh. Climate and Development, 7(2), 110-123. https://doi. org/10.1080/17565529.2014.934771.

Jutla, A., Whitcombe, E., Hasan, N., Haley, B., Akanda, A., Huq, A., et al. (2013). Environmental factors influencing epidemic cholera. American Society of Tropical Medicine and Hygiene, 89(3), 597-607.

Keller, M., Zamudio, A. N., Bizikova, L., Sosa, A. R., \& Gough, A. M. (2018). Food security and climate change from a systems perspective: Community case studies from Honduras. Climate and Development, 10(8), 742-754.

Krishnamurthy, P. K., Lewis, K., \& Choularton, R. J. (2014). A methodological framework for rapidly assessing the impacts of climate risk on national-level food security through a vulnerability index. Global Environmental Change - Human and Policy Dimensions, 25, 121-132.

Lauria, V., Das, I., Hazra, S., Cazcarro, I., Arto, I., Kay, S., et al. (2018). Importance of fisheries for food security across three climate change vulnerable deltas. Science of the Total Environment, 640-641, $1566-1577$.

Leroy, J. L., Ruel, M., Frongillo, E. A., Harris, J., \& Ballard, T. J. (2015). Measuring the food access dimension of food security: A critical review and mapping of indicators. Food and Nutrition Bulletin, 36(2), 167-195.

Liersch, S., Cools, J., Kone, B., Koch, H., Diallo, M., Reinhardt, J., et al. (2013). Vulnerability of rice production in the inner Niger Delta to water resources management under climate variability and change. Environmental Science \& Policy, 34, 18-33.

Masterson, J. P., \& Garabedian, S. P. (2007). Effects of sea-level rise on ground water flow in a coastal aquifersystem. Ground Water, 45(2), 209-217.

McElwee, P., Nghiem, T., Le, H., \& Vu, H. (2017). Flood vulnerability among rural households in the red River Delta of Vietnam: Implications for future climate change risk and adaptation. Natural Hazards, 86, 465-492.

Minar, M., Hossain, M., \& Shamsuddin, M. (2013). Climate change and coastal zone of Bangladesh: Vulnerability, resilience and adaptability. Middle-East Journal of Scientific Research, 13(1), 114-120.

Nelson, R., Kokic, P., Crimp, S., Meinke, H., \& Howden, S. M. (2010). The vulnerability of Australian rural communities to climate variability and change: Part I - conceptualizing and measuring vulnerability. Environmental Science and Policy, 13, 8-17.

Neumann, J. E., Emanuel, K. A., Ravela, S., Ludwig, L. C., \& Verly, C. (2015). Risks of coastal storm surge and the effect of sea level rise in the red River Delta, Vietnam. Sustainability, 7(6), 6553-6572. https://doi.org/10.3390/su7066553.

Nguyen, H.N. (2007). Flooding in Mekong River Delta, Vietnam. UNDP ocassional paper 2007/53. Available at file:///E:/ F S_m a n u s r i p t_r e s u b m i s s i o n/ Mamun\%20data\%20 analys is $\% 20$ on $\% 20$ holiday/ Mamun\%20data\%20analysis/literature/Nguyen\%202007disease \%20flood\%20vietnam\%20delta.Pdf (last accessed on 20/09/ 2019).

Nicholls, R. J., Hutton, C. W., Adger, W. N., Hanson, S. E., Rahman, M. M., \& Salehin, M. (Eds.). (2018). Ecosystem Services for Well-being in deltas - Integrated assessment for policy analysis. Switzerland: Palgrave Macmillan.

Oo, A. T., Huylenbroeck, G. V., \& Speelman, S. (2018). Assessment of climate change vulnerability of farm households in Pyapon District, a delta region in Myanmar. International Journal of Disaster Risk Reduction, 28, 10-21.

Parvin, G., \& Shaw, R. (2013). Microfinance institutions and a coastal community's disaster risk reduction, response, and recovery process: A case study of Hatiya, Bangladesh. Disasters, 37(1), 165184.

Parvin, G. A., Takahashi, F., \& Shaw, R. (2008). Coastal hazards and community coping methods in Bangladesh. Journal of Coastal Conservation, 12, 181-193.

Piya, L., Joshi, N. P., \& Maharjan, K. L. (2016). Vulnerability of Chepang households to climate change and extremes in the Mid-Hills of Nepal. Climatic Change, 135, 521-537. https://doi.org/10.1007/ s10584-015-1572-2.

Quader, M. A., Khan, A. U., \& Kervyn, M. (2017). Assessing the risks from cyclones for human lives and livelihoods in the coastal region of Bangladesh. International Journal of Environmental Research 
and Public Health, 14, 831. https://doi.org/10.3390/ ijerph14080831.

Rasul, G., Mahmood, A., Sadiq, A., \& Khan, S. I. (2012). Vulnerability of the Indus Delta to climate change in Pakistan. Pakistan Journal of Meteorology, 8(16), 89-107.

Sen, A. K. (1981). Poverty and famines: An essay on entitlement and deprivation. Oxford: Clarendon Press.

Shamsuddoha, M. \& Chowdhury, R.K. (2007). Climate Change Impact and Disaster Vulnerabilities in the Coastal Areas of Bangladesh. Dhaka: COAST Trust.

Siddiqui, M. R. (2014). Patterns and factors of out-migration in the Meghna Estuarine Islands of Bangladesh. GEOGRAFIA online. Malaysian Journal of Society and Space, 10(1), 11-24.

Sietz, D., Choque, S. E. M., \& Ludeke, M. K. B. (2012). Typical patterns of smallholder vulnerability to weather extremes with regard to food security in the Peruvian Altiplano. Regional Environmental Change, 12(3), 489-505.

Smit, B., \& Wandel, J. (2006). Adaptation, adaptive capacity and vulnerability. Global Environmental Change, 16(3), 282-292.

Star Country Desk (2013, August 21). Over 60 villages flooded in Bhola, Hatiya. Retried from https://www.thedailystar.net/news/over-60villages-flooded-in-bhola-hatiya (accessed on 16/09/2019).

Thathsarania, U. S., \& Gunaratneb, L. H. P. (2018). Constructing and index to measure the adaptive capacity to climate change in Sri Lanka. Procedia Engineering, 212, 278-285.

Tran, H., Nguyen, Q., \& Kervyn, M. (2017). Household social vulnerability to natural hazards in the coastal tan Van Thoi District, Ca Mau Province, Mekong Delta, Vietnam. Journal of Coastal Conservation, 21(4), 489-503.

van Soesbergen, A., Nilsen, K., Burgess, N.D., Szabo, S., \& Matthews, Z. (2017). Food and nutrition security trends and challenges in the Ganges Brahmaputra Meghna (GBM) delta. Elementa science of the Anthropocene, 5: 56, https://doi.org/10.1525/elementa.153.

Vincent, K. (2007). Uncertainty in adaptive capacity and the importance of scale. Global Environmental Change, 17(1), 12-24.

Vincent, K., \& Cull, T. (2010). A household social vulnerability index (HSVI) for evaluating adaptation projects in developing countries. Paper presented in PEGNet conference 2010, policies to Foster and Sustain equitable development in times of crises, Midrand, 2nd-3rd September 2010.

WFP (World Food Programme). (2008). Food consumption analysis: Calculation and use of the food consumption score in food security analysis. Rome: FAO.

WFP. (2017). Creation of a wealth index. VAM guidance paper. Available at: https://docs.wfp.org/api/documents/WFP-0000022418/ download/? ga=2.156326329.343949792.15435019881745710939.1423496269 (accessed 29/11/2018).

Woodruff, J. D., Irish, J. L., \& Camargo, S. J. (2013). Coastal flooding by tropical cyclones and sea-level rise. Nature, 504, 44-52.

Wright H., Kristjanson P., \& Bhatta G. (2012). Understanding adaptive capacity: Sustainable livelihoods and food security in coastal Bangladesh. CCAFS working paper no. 32. CGIAR research program on climate change, agriculture and food security (CCAFS), Copenhagen, Denmark. Available online at: www.ccafs.cgiar.org.
Yang, S. L., Milliman, J. D., Li, P., \& Xu, K. (2011). 50,000 dams later: Erosion of the Yangtze River and its delta. Global and Planetary Change, 75(1-2), 14-20.

Žurovec, O., C`adro, S., \& Sitaula, B. K. (2017). Quantitative assessment of vulnerability to climate change in rural municipalities of Bosnia and Herzegovina. Sustainability, 2017(9), 1208. https://doi.org/10. 3390/su9071208.

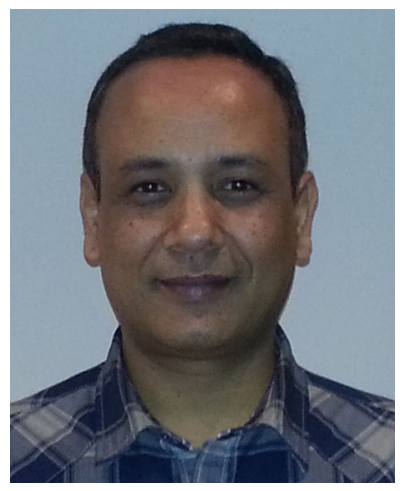

Dr Islam is a senior lecturer at Nottingham Trent University (NTU) in the UK. He has over 20 years of experience in teaching, research, and developmental activities in the broad areas of sustainable agriculture and food security, both in developed and developing country contexts. Dr. Islam holds a $\mathrm{PhD}$ from Massey University New Zealand and has worked for Bangladesh Agricultural University, Open University UK, Scotland's Rural College ( SRUC), and Nottingham Trent University. Dr. Islam has been involved in a range of international development projects funded by the World Bank, DFID, JSPS and industry. Dr. Islam is the programme leader for the MSc/ MRes in Global Food Security \& Development courses at NTU.

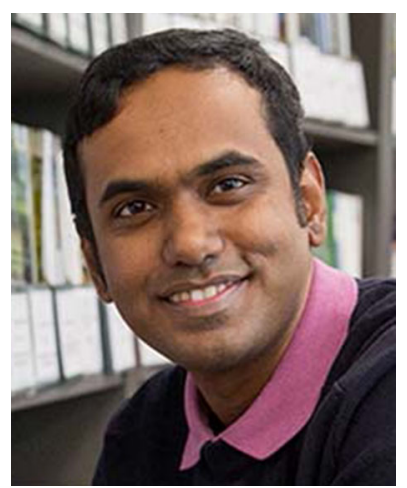

Mr Mamun is an Assistant Professor at Noakhali Science \& Technology University (NSTU) in Bangladesh. He teaches food science and nutrition and has been involved with a range of developmental activities in the Southern coastal areas of Bangladesh. Mr. Mamun holds an MSc degree in Global Food Security \& Development from Nottingham Trent University, UK. 